Review

\title{
Additive Manufacturing Techniques for Fabrication of Bone Scaffolds for Tissue Engineering Applications
}

Babak Jahani ${ }^{1,}{ }^{*}$, Xinnan Wang ${ }^{1}$, Amanda Brooks ${ }^{2,3}$

1. Department of Mechanical Engineering, North Dakota State University, Fargo, ND 58108, USA; EMails: babak.jahani@ndsu.edu; xinnan.wang@ndsu.edu

2. Department of Research and Scholarly Activity, Rocky Vista University, Ivins, UT 84738, USA; E-Mail: abrooks@rvu.edu

3. Department of Molecular Biology, Rocky Vista University, Ivins, UT 84738, USA

* Correspondence: Babak Jahani; E-Mail: babak.jahani@ndsu.edu

Academic Editor: Devendra Verma

Special Issue: Biomimetic Materials Design as an Inspiration to Additive Manufacturing

Recent Progress in Materials

2020, volume 2, issue 3

doi:10.21926/rpm.2003021
Received: June 26, 2020

Accepted: September 1, 2020

Published: September 8, 2020

\begin{abstract}
Bone tissue engineering (BTE) as a modern and more effective treatment for bone defects has recently received lots of attention. One of the pivotal parts of BTE is the "scaffold", which functions as an indwelling carrier of cells and additives, as well as, providing a foundation for cell growth and eventually forming new, native-like bone. Up to now, many methods and materials have been employed to manufacture bone scaffolds. This review focuses on providing both basic knowledge of BTE as well as possible methods of scaffold manufacturing. We categorize the fabrication methods into; current conventional methods and newly emerging additive manufacturing ( $A M)$ techniques. The fundamental, capabilities and limitations of each technique is investigated, and the latest achievements are presented.
\end{abstract}

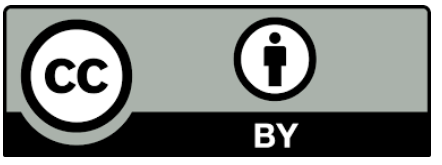

(C) 2020 by the author. This is an open access article distributed under the conditions of the Creative Commons by Attribution License, which permits unrestricted use, distribution, and reproduction in any medium or format, provided the original work is correctly cited. 


\section{Keywords}

Bone scaffolds; additive manufacturing methods; tissue engineering

\section{Introduction}

Bone defects due to fractures, diseases or surgeries (e.g., tumor removal or total joint replacement) not only can cause pain and dysfunction but also can impose staggering socioeconomic costs. Although bone degradation with age leads directly to pain in many cases, it is considered a "silent" and "progressive" disorder that may eventually lead to deformity and fracture. According to American Academy of Orthopedic Surgeons (AAOS), by 2030, total hip and knee replacements are expected to grow up to $171 \%$ and $189 \%$, respectively. Approximately one in two women and one in four men over age 50 will have an osteoporosis-related fracture with an accompanying $20 \%$ mortality rate within the first year after a hip fracture. Aging US population in addition to a rise in obesity accompanied by an increasingly inactive lifestyle further complicate the treatment of bone diseases, comprising a burgeoning national healthcare crisis. Conventional methods to address bone-related diseases, appear inefficient or in some cases are incompatible with the prolonged life expectancy in modem societies. Numerous studies have shown the serious limitations and complications of conventional treatments for bone diseases [1-7]. Despite advances in treatments for the health and quality of life, bone loss with its consequent defects, vascularization issues, soft-tissue damage, inadequate mechanical stability and infections remain significant challenges for patients and doctors [8]. Recently, bone tissue engineering has emerged as an effective biomimetic technique and an alternative to current conventional bone repairs. Similar to other areas of bone tissue engineering is considered regenerative and self-healing, intending to induce bone growth through synergic, integrated factors such as biomaterials, physical scaffold design, host cells and rehabilitation parameters. In other words, scaffolds made with biomaterials can serve as templates, providing a tissue microenvironment suitable for cell viability, adhesion, proliferation, osteogenic differentiation, vascularization, host integration and, where necessary, load bearing [9]. One of the most promising scaffold fabrication methods particularly adept in bone tissue engineering is additive manufacturing (AM). The term "additive manufacturing" refers to a group of technologies capable of creating a precise, three-dimensional object one layer at a time using metals, ceramics, polymers "resins" or biological protein "bio-inks". Each successive layer bonds to the preceding layer of melted or partially melted material. So far different AM processes have been introduced for variety of research and industrial applications. Particularly in biomedical applications, AM processes are significantly important due to their capabilities to provide extensive customization based on specifications and requirements of each individual patient.

This review aims to provide an updated source on bone scaffolds and their fabrication methods as a guide for the readers on this rapidly growing field. In this paper, an overview on the concepts of tissue engineering, bone tissue engineering, scaffolds and the materials will be addressed. And then, the conventional and new methods of fabrication will be reviewed and the strengths and drawbacks of each method will be discussed. 


\section{Tissue Engineering}

\subsection{Background}

According to the US National Institute for Biomedical Imaging and Bioengineering (NIBIB), tissue engineering (TE) refers to the practice of combining scaffolds, cells, and biologically active molecules into functional tissues [10]. The goal of TE is to restore, maintain, or improve biological function of damaged tissues or whole organs that have been lost due to congenital abnormalities, injury, disease, or aging [11]. TE involves (1) the revival of tissues and cells from their natural biological environment, (2) growth, proliferation and/or manipulation of the cells and tissues in vitro, and (3) reintroduction of the cells or tissue into the biological microenvironments. Alternatively, TE can also refer to direct regeneration in vivo. The concept of TE can even go beyond the therapeutic purposes, being used as a biosensor for diagnostic intentions $[12,13]$. Historically, as described in Sanskrit texts of India, the first tissue-based therapies were described around 3000 years ago when skin grafting was used to reconstruct noses that were amputated as a means of judicial punishment $[14,15]$. Although in some sense the purpose of TE hasn't changed, being still aimed at restoring both form and function, the history of modern tissue engineering goes back to the early 1970's when the concept of cell-based tissue engineering emerged. The first tissue-engineered skin was constructed by Green and his colleagues at Harvard Medical School [16]. They introduced a technique to grow skin epidermis starting with a skin biopsy harvested from a patient. Keratinocytes isolated from the biopsy could be proliferated by co-culturing with a feeder layer of mouse mesenchymal cells, thus expanding the coverage area several thousand-fold within weeks [17-19]. Also at early stages, Bell with his coworkers at MIT developed a composite skin product reconstituting both dermis and epidermis. In their research, the dermis is first made by seeding a collagen gel with dermal fibroblasts, which causes the gel to contract and form a neodermis [20]. In 1990s, pioneers such as Atala with his group, started to create bladder, skin, cartilage, urethra, muscle and vaginal organs which later some of them were successfully implanted in patients [21]. By late 90s, several of collagen-based and other tissue-engineered skins and cartilage products were successfully commercialized. These early successes fueled much enthusiasm, and many research laboratories embarked on applying tissue engineering to nearly every tissue in the body [22]. During the progression of tissue engineering over the past four decades, several technologies (cell engineering, self-assembly, bioprinting, mechanobiology and etc.) have been introduced, allowing the field of tissue engineering to advance quickly. Advances in molecular and cellular biology, as well as, engineering breakthroughs such as micro and nano systems and additive manufacturing, computational analysis and simulations significantly extended the concept of tissue engineering [2326]. Currently, even though some therapies have received approval or clearance from Food and Drug Administration (FDA) and are commercially available, many challenges remain to be solved in order to serve effectively the wide range of patient needs. Table 1 shows some of the FDA approved tissue engineering products available in the clinical market. 
Table 1 Some examples of FDA Approved Tissue Engineering Therapies.

\begin{tabular}{|c|c|c|c|c|}
\hline $\begin{array}{l}\text { Human } \\
\text { Organ }\end{array}$ & Product & Company & Application & Reference \\
\hline \multirow{5}{*}{ Skin } & Apligraf & Organogenesis & $\begin{array}{l}\text { For treatment of non-infected } \\
\text { partial and } \\
\text { full-thickness skin ulcers }\end{array}$ & [27] \\
\hline & $\begin{array}{l}\text { Composite } \\
\text { Cultured Skin }\end{array}$ & $\begin{array}{l}\text { Ortec } \\
\text { International }\end{array}$ & $\begin{array}{l}\text { covering wounds and donor sites } \\
\text { after surgery }\end{array}$ & [28] \\
\hline & & & & \\
\hline & Dermagraft & Smith \& Nephew & Treatment of wounds & [29] \\
\hline & laViv & Fibrocell Science & $\begin{array}{l}\text { Improving nasolabial fold } \\
\text { appearance }\end{array}$ & [30] \\
\hline \multirow{4}{*}{ Bone } & Carticel & Genzyme & Repair of femoral condyle & [31] \\
\hline & OP-1 Implant & Stryker Biotech & $\begin{array}{l}\text { Alternative to autograft in } \\
\text { recalcitrant } \\
\text { long bone nonunions }\end{array}$ & [32] \\
\hline & $\begin{array}{l}\text { InFUSE Bone } \\
\text { Graft }\end{array}$ & Medtronic & $\begin{array}{l}\text { Spinal fusion for degenerative } \\
\text { disc disease }\end{array}$ & [33] \\
\hline & GEM 21S & $\begin{array}{l}\text { Biomimetic } \\
\text { Pharmaceuticals }\end{array}$ & $\begin{array}{l}\text { Treatment for periodontally } \\
\text { related defects }\end{array}$ & [34] \\
\hline
\end{tabular}

\subsection{Tissue Engineering: Biological Approaches}

Currently there are two main approaches in tissue engineering; acellular and cellular. The acellular approach involves the use of natural or synthetic matrices to encourage the body's natural ability to repair itself and help the new tissue grow [35]. The cellular approach uses donor cells either alone or implanted into the scaffold for new tissue formation [36]. In addition to blood cells, the human body possesses around $10^{13}$ tissue cells, but not all these cells have the capability to regenerate [37]. Stem cells are the main supplying source of cells for tissue engineering [38]. These types of cells with capacity to continually divide, serve in many tissues as a sort of internal healing and restoration system. Stem cells differ from other kinds of cells in the body. Remarkably, when a stem cell divides, each new cell is potentially capable of retaining it "stemness" or differentiating into a specialized cells, such as a brain cell, red blood cell or a muscle cell. Figure 1 shows some of potential applications of human stem cells. The inherently unspecialized character of stem cells means they originally do not have any tissue- 
specific structures but under certain physiologic or experimental conditions they can be induced to express the structure of specialized cells [39]. Stem cells can be extracted from three major sources in live human; embryonic stem cells, gestational tissue stem cells and tissue-derived adult stem cells. Adult stem cells have been identified in many organs and tissues, including brain, bone marrow, peripheral blood, blood vessels, skeletal muscle, skin, teeth, heart, liver, ovarian epithelium, and testis.

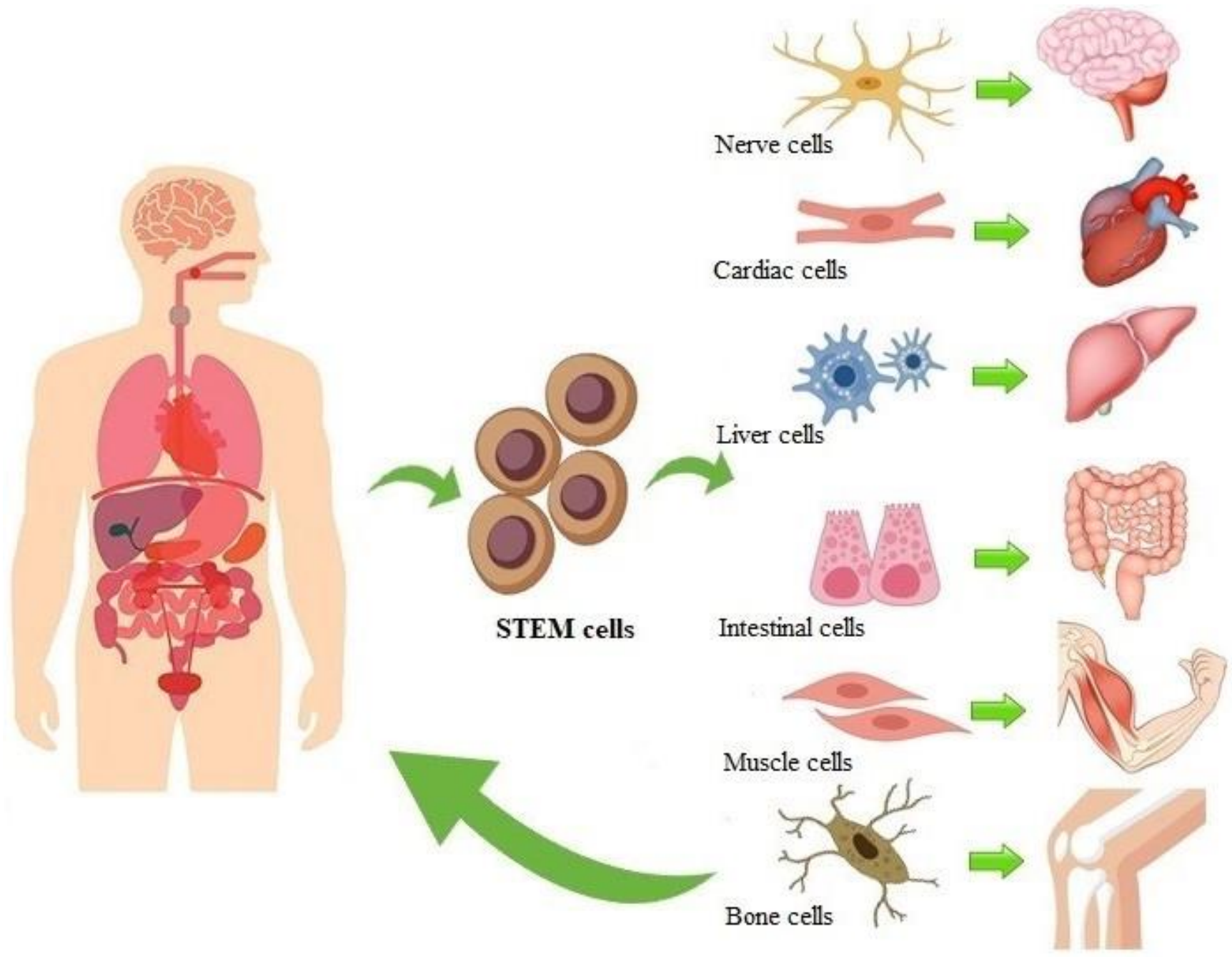

Figure 1 The differentiation capacity of adult stems for tissue engineering applications.

In addition to the cellular components of tissue engineering, the formation of an artificial tissue requires the presence of a scaffold, which behaves as a template for tissue growth in both the cellular and acellular approaches to tissue engineering. In addition to fulfilling its primary role as a cell carrier and new tissue foundation, scaffolds can also be equipped as pharmaceutical or bio molecule delivery vehicles (e.g., antibacterial [40-43] or growth factors [44]). As schematically shown in Figure 2, tissue engineering is a multidisciplinary research field founded on three major components: the scaffold, the cells, and growth factors. Although each of these areas presents challenges and complications which 
must be addressed, this review takes an engineering and manufacturing approach to fundamental aspects of scaffold design and fabrication.

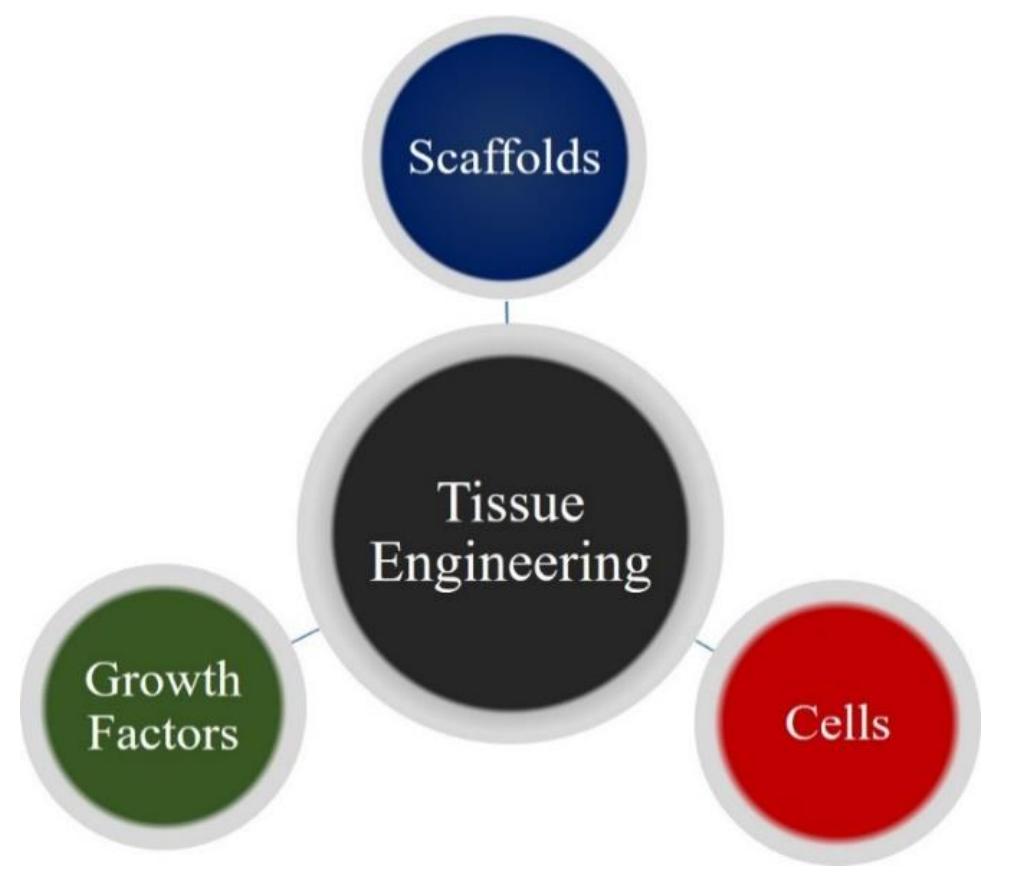

Figure 2 The three main components of Tissue Engineering.

\section{Bone Tissue Engineering}

Bone is the second most transplanted tissue after the blood. Annually more than two million bone graft operations are performed worldwide, of which almost 1.6 million take place in the USA $[45,46]$. Bone grafts are being used in cases of trauma, osteonecrosis, tumor lesions, skull injury and etc. [47, 48]. Furthermore, based on the severity of the case, implementation of substitutional supportive materials may be needed. However, in cases where donor availability is limited, or there is possibility of disease transmission, donor site complications or even limitations of external materials to reshape and respond to physiological conditions, bone tissue engineering is considered an alternative. Regardless of whether bone tissue engineering occurs by providing an acellular scaffold to support existing bone growth [49] or by providing a scaffold seeded with stem cells, which can directly differentiate to bone cells [50] to replace a damaged section of bone, the composition and structure of the scaffold is key [51]. In fact, a primary aim of bone tissue engineering is to produce scaffolds, which not only act as a structure for implantation of cells, but also provide regenerative signals to cells to enhance bone healing [52]. Despite these clear objectives and commercially successful bone tissue engineering products such as Infuse ${ }^{\circledR}$ (Medtronic Inc., MN, USA) and ACTIFUSE (Baxter International Inc., IL, USA) [53], achievements in this field are not meeting the huge clinical demands [54, 55]. Figure 3 shows the schematic process of bone tissue engineering. 


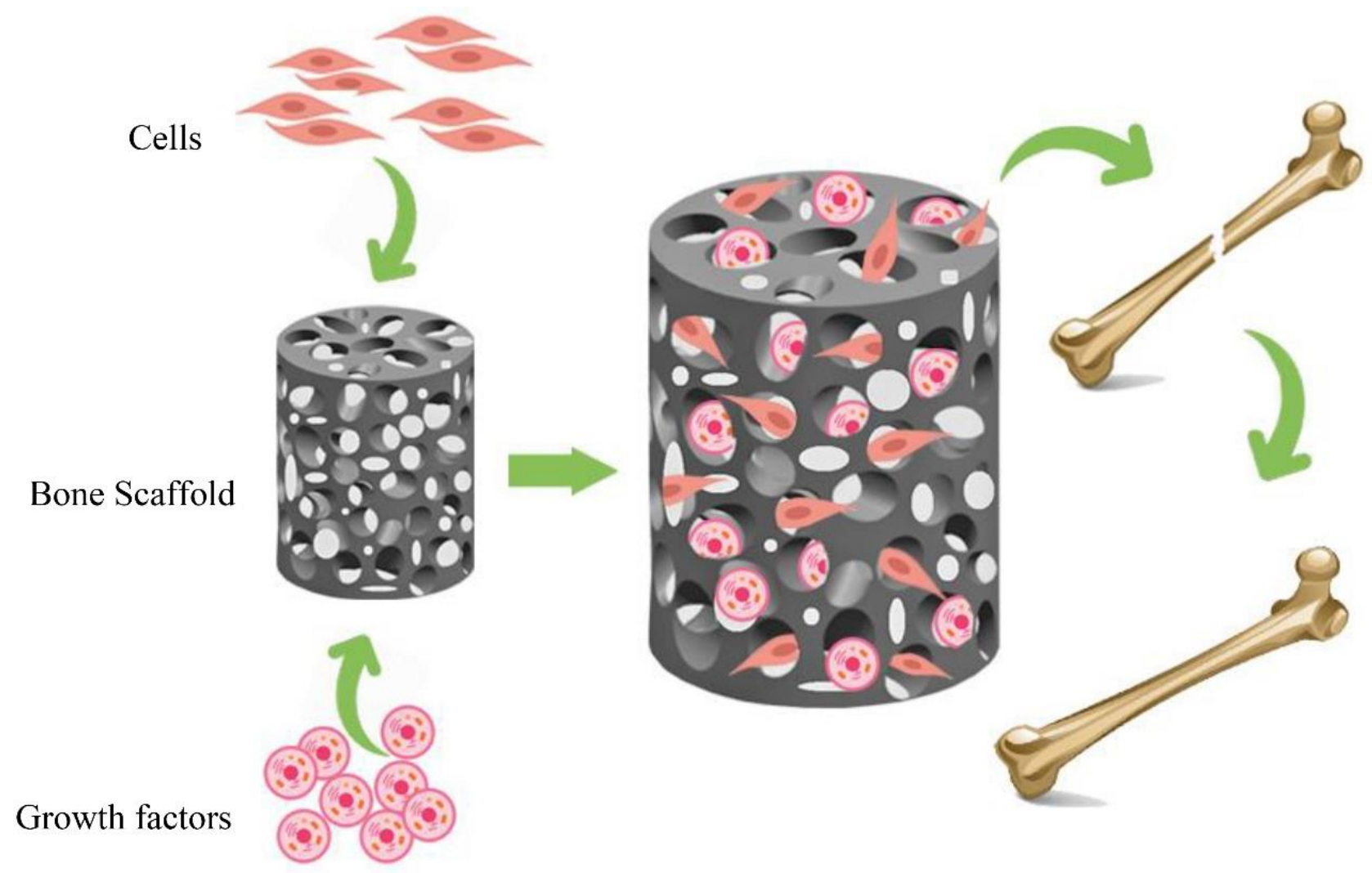

Figure 3 Schematic bone tissue engineering process.

\section{Bone Scaffolds}

Bone scaffolds as it can been seen in Figure 4 are 3D architecture and environment, which are designed to (1) promote cell adhesion, survival, migration and proliferation, (2) accelerate bone remodeling, (3) provide osteoconductive structural guidance, and (4) in some cases, act as carrier for growth factors, antibiotics or gene therapy [56-58]. With all of these functional demands, optimal scaffolds must have certain properties as highlighted below:

- Biocompatibility: Incorporation into the host tissue without toxic effects and/or provoke an immune reaction $[59,60]$.

- Biodegradability: Degradation in vivo at a controlled resorption rate that equals the bone formation rate, so that when the lesion is fully regenerated, the scaffold has been degraded or completely integrated $[59,60]$.

- Porosity: Interconnections of pores to promote vascularization, diffusion of nutrients and gases, and removal of metabolic wastes as a result of cellular activity. It has been shown that scaffolds with a minimum pore size of $150 \mu \mathrm{m}$ and a mean pore size of $300 \mu \mathrm{m}$ are optimal for bone tissue formation $[61,62]$.

- Surface properties: Adhesion and proliferation of cells due to topographic features such surface roughness $[59,60]$. 
- Mechanical properties: Acclimatization to the mechanical properties of hosting bone. For example, human cancellous bone has a compressive strength between 2 and $12 \mathrm{MPa}$ and an elastic modulus between 0.1 and $5 \mathrm{GPa}$ [63]. It means the implemented scaffold in cancellous bone must the similar mechanical properties.

- $\quad$ Radiolucency: Inspection and evaluation the progress of new bone formation by radiography techniques. $[59,60]$.

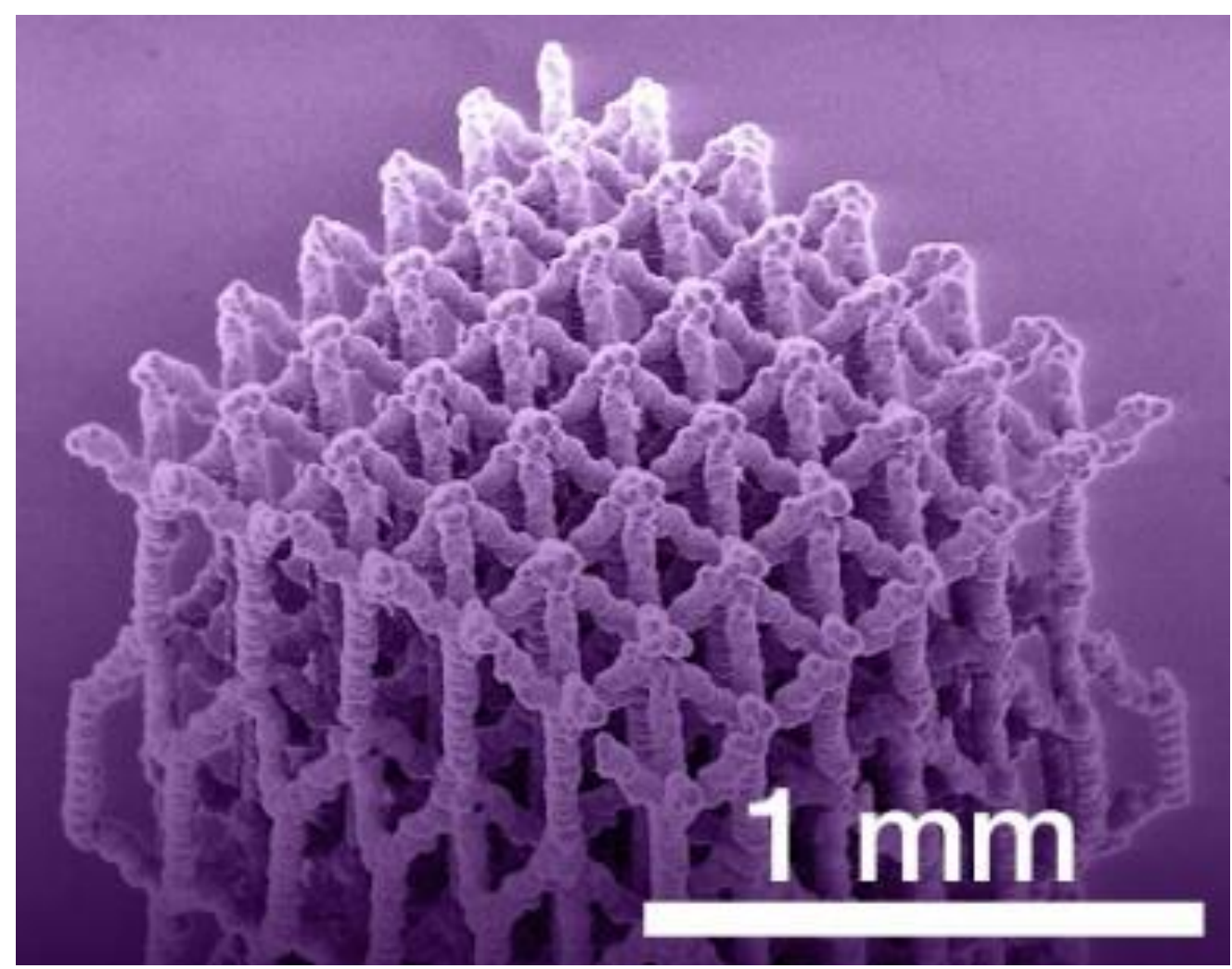

Figure 4 Actual bone scaffold fabricated by 3D printing [64].

\section{Scaffolds Materials}

Ideally, the best materials for fabrication of bone scaffolds are materials which can mimic the natural environment and function of human bone. To achieve this goal, the candidate biomaterials for bone scaffold applications should have one or more of the following functions.

- Promote cell adhesion and migration

- Enhance vascularization

- Facilitate diffusion of vital cell nutrients and secreted products

- Support mechanical and biological functions

In this regard, different categories of materials such as metals, ceramics, polymers and their composites have been investigated [65]. These different materials and their key advantages and limitations are summarized in Table 2. 
Table 2 Some of biocompatible materials for bone scaffold fabrication.

\begin{tabular}{|c|c|c|c|c|}
\hline $\begin{array}{l}\text { Scaffold } \\
\text { material }\end{array}$ & Examples & Advantages & Disadvantages & References \\
\hline \multirow[b]{2}{*}{ Metals } & $\mathrm{NiTi}$ & High young's modulus & Not degradable & \multirow[b]{2}{*}{ [66-59] } \\
\hline & Porous tantalum & $\begin{array}{l}\text { High compressive } \\
\text { strength }\end{array}$ & Ion release & \\
\hline \multirow{2}{*}{ Ceramics } & $\mathrm{TiO}_{2}$ & $\begin{array}{l}\text { Osteogenic, } \\
\text { biocompatible }\end{array}$ & Brittle & \multirow{2}{*}[70-74]{} \\
\hline & Hydroxyapatite & Can be biodegradable & $\begin{array}{l}\text { Prone to fracture and } \\
\text { fatigue }\end{array}$ & \\
\hline $\begin{array}{l}\text { Natural } \\
\text { Polymers }\end{array}$ & $\begin{array}{l}\text { Collagen } \\
\text { Chitosan }\end{array}$ & $\begin{array}{l}\text { Biocompatible, } \\
\text { Biodegradable } \\
\text { Osteogenic }\end{array}$ & $\begin{array}{l}\text { Low mechanical } \\
\text { strength }\end{array}$ & {$[75-77]$} \\
\hline $\begin{array}{l}\text { Synthetic } \\
\text { Polymers }\end{array}$ & PLGA & Tunable properties & $\begin{array}{l}\text { Acidic degradation } \\
\text { byproducts } \\
\text { Rapid strength } \\
\text { degradation in vivo }\end{array}$ & [78- 81] \\
\hline
\end{tabular}

\subsection{Metals}

Due to formability and mechanical strength specifically in load-bearing applications, metals have always been attractive candidates for biomaterial applications. Metals such as titanium, magnesium or stainless steel have been used for joint prostheses, plates and screws [82]. Even though metals have big advantages for bone scaffold applications, it should be noted that since most metals have elastic moduli much higher than those of human bones, stress shielding and resorption of the surrounding bone tissue can be a deleterious consequence [63]. This drawback has been solved to some extent by increasing the porosity in the microstructure of implants, which also can have positive effect on vascularization and cell adhesion within the scaffold. For example, He et al. decreased the elastic modulus of a titanium scaffold from 1.22 to $0.18 \mathrm{Gpa}$, which is close to elastic modulus of cancellous bone, by increasing the porosity from $44.2 \%$ to $65.1 \%$ [83]. The non-degradability of metals such as Ti, $\mathrm{Co}, \mathrm{Al}$ and $\mathrm{V}$, is the main drawback limiting their use as scaffold material. Over time cells invade the scaffold pores forming new bone tissues; unfortunately, the long-term presence of metals within the tissue creates health issues such as alzheimer, infertility, neurological and cardiological symptoms [84]. One solution includes the fabrication of magnesium alloy-based highly porous scaffolds, which can degrade in vivo by corrosion. However, even though magnesium degradation has been shown to stimulate bone-healing, concerns remain regarding the inflammatory response to the degradation of metals in vivo, as well as, the body's ability to clear the corrosion products [85]. Fatigue, ion-releasing, corrosion, lack of integration with host tissue, which can lead to the formation of fibrous tissue, and risk of infection are other issues of metallic scaffolds [73]. 


\subsection{Ceramics}

Ceramics have been used in orthopedic applications either as implants or coatings for implants. Ceramics such as hydroxyapatite and tricalcium phosphate (TCP) are among the most widely used materials for bone substitution due to their compositional similarity to bone mineral and excellent chemical biocompatibility $[73,86]$. Hydroxyapatite supports the growth of bone cells (osteoconduction) along its surface or within the pores by providing a porous structure similar to that of natural bone [87]. Moreover, as a hydroxyapatite scaffold degrades in the body over the time, it releases calcium and phosphate ions, which stimulates new bone formation (osteoinduction) [88]. One of great advantages of TCP and hydroxyapatite for bone scaffold applications is that they have shown minimal immunogenicity or toxic consequences [58]. Ceramics present high compressive strength, close to that of trabecular bone [82] and can be manufactured into highly interconnected macroporous structures $[89,90]$ thereby increasing vascularization, nutrient delivery and bone ingrowth [77, 91, 92]. Calcium phosphate ceramics such as hydroxyapatite can present more adaptable biodegradability compared to other ceramics [73]. One of the biocompatible ceramics, which has recently been applied for bone tissue engineering and drug delivery system, is Laponite ${ }^{\circledR}$ (LAP). LAP is a kind of silicate based nanoparticles with chemical formula $(\mathrm{Mg}, \mathrm{Li})_{3} \mathrm{Si}_{4} \mathrm{O}_{10}(\mathrm{OH})_{2} \mathrm{Na}_{3}$ and disc-shaped morphology with the diameter of $25 \mathrm{~nm}$ and the thickness of $1 \mathrm{~nm}$. LAP consists of negative face charge and feebly positive edge charge leading to strong interaction with polymers to develop nanocomposites with excellent physical and mechanical properties. Previous studies revealed that clay based nanocomposites could simultaneously improve durability, mechanical strength, thermal stability, gas-barrier properties, surface characteristics and biocompatibility making them promising for various tissue engineering applications. For instance, researches demonstrated that LAP nanoplates could promote cell proliferation and encourage the osteogenic differentiation of human mesenchymal stem cells (MSCs) in the lack of osteoinductive functions.

Along with the mentioned advantages, ceramics have disadvantages too, for example poor performance in load-bearing conditions and brittleness have limited the use of ceramics in loaded bone applications [71]. One solution is to use composites of ceramics instead of ceramic alone. For instance, a composite of ceramic and polymer can exhibit the excellent biocompatibility of ceramics as well as durability of polymers.

\subsection{Polymers}

Polymeric scaffolds are considered very good choices for bone tissue engineering due to the excellent tunable and adaptable characteristics. In particular, biodegradable polymers, can be designed to support tissue growth until needed and then be resorbed by the body [62].

\subsubsection{Synthetic Polymers}

Common synthetic polymers for bone tissue applications include poly (glycolic acid), poly (lactic acid), copolymers of poly (DL-lactic-glycolic acid) (PLGA), polycaprolactone (PCL) and many others [93]. Fabrication of scaffolds using synthetic polymers has many advantages such as the possibility of tuning 
the mechanical properties and fabrication of complex structures as well as controlling the degradation rate [82]. Despite the wide range of properties provided by organic polymers, the lack of bioactivity is a major drawback of these types of materials [94]. To solve this issue, synthetic polymers have been used as a composite with other materials. For example, cellulose nanocrystals (CNCs) were added to polyacrylamide (PAAm) polymers matrix to improve bioactivity by increasing the biomineralization rate [95]. Another problem associated with synthetic materials for scaffold applications is their acidic degradation or toxic degradation byproducts, which can adversely affect the tissue growth. [73, 93]. Physical characteristics of synthetic polymers can also limit their application as bone scaffolds. For example, poly (L-lactic acid) or PLLA is hydrophobic which consequently cause the lack of homogeneous integration of proteins and poor cell attachment to the surface [96].

\subsubsection{Natural Polymers}

Natural polymers such as collagen, silk fibroin, chitosan, alginate and hyaluronic acid have recently received attention as bone scaffolds due to their superior chemical biocompatibility, low immunogenicity, and proven ability to facilitate cell growth [93]. One additional important advantage of natural polymers is the possibility of tuning and optimization of process factors such as concentration, charge, chemical addition in order to get desired properties [56]. Also, the presence of ligands such as bone morphogenetic protein 2 (BMP-2) in natural polymers has been shown to facilitate bone cell adhesion [86]. Natural polymer hydrogels can create 3D scaffolds with the ability to absorb large amounts of water $[97,98]$. With their soft and flexible structure, hydrogels can be used for cell encapsulation, minimizing the amount of damage to the host tissue [99, 100]. Gelatin methacryloyl (GeIMA) hydrogels have been widely used for various biomedical applications due to their suitable biological properties and tunable physical characteristics. Three dimensional (3D) GelMA hydrogels closely resemble some essential properties of native extracellular matrix (ECM) due to the presence of cell-attaching and matrix metalloproteinase responsive peptide motifs, which allow cells to proliferate and spread in GelMA-based scaffolds. GelMA is also versatile from a processing perspective. It crosslinks when exposed to light irradiation to form hydrogels with tunable mechanical properties which mimic the native ECM. It can also be microfabricated using different methodologies including micromolding, photomasking, bioprinting, self-assembly, and microfluidic techniques to generate constructs with controlled architectures. Hybrid hydrogel systems can also be formed by mixing GelMA with nanoparticles such as carbon nanotubes and graphene oxide, and other polymers to form networks with desired combined properties and characteristics for specific biological applications. Recent research has demonstrated the proficiency of GelMA-based hydrogels in a wide range of applications including engineering of bone, cartilage, cardiac, and vascular tissues, among others. Other applications of GelMA hydrogels, besides tissue engineering, include fundamental single-single cell research, cell signaling, drug and gene delivery, and bio-sensing.

Some limitations of natural polymers are the difficulty in controlling their degradation rate as well as low mechanical stability [78]. Since collagen is abundant in bone tissue [86], collagen hydrogels are inherently biocompatible and biodegradable, highly porous, minimally antigenic and can easily be combined with other materials [76]. A limitation of collagen-based scaffolds is the relatively poor 
mechanical properties. Silk fibroins offer excellent mechanical properties, biocompatibility and versatility in processing [77]. Silk fibroin is environmentally stable, flexible and degradable by proteolytic enzymes [101]. Chitosan can be extracted from skeletal materials of crustaceans, mushroom envelopes, green algae cell walls and yeast [100]. It has been shown that chitosan has a superior ability to promote cell adhesion and growth [56, 102]. Moreover, it can show antibacterial, analgesic, hemostatic and mucoadhesive properties [103, 104]. Like other natural polymers, the limitation of chitosan for use as a bone scaffold is its poor mechanical strength.

\section{Fabrication of Scaffolds}

Manufacturing techniques for fabrication of bone scaffolds can be categorized in two major methods; conventional and modern methods. Conventional methods are mostly based on subtractive manufacturing techniques in which parts of the material are removed from an initial block to reach the desired geometry. Modern techniques are based on the concept of additive manufacturing, in which material is successively added layer by layer.

\subsection{Conventional Techniques}

\subsubsection{Sol-Gel Technique}

Generally, sol-gel is defined as a chemical process that involves three main steps: (a) preparation of a liquid with colloidal particles (sol), which neither dissolve nor agglomerate (b) condensation/polymerization of monomers of the sol (gelation) and (c) removal of the solvent [105]. The process is influenced by several parameters such as $\mathrm{pH}$, temperature, concentration of the reactants, and presence of additives. This process is mainly used for fabrication of ceramic or glass materials in the form of ultra-fine or spherical-shaped powders, thin-film coatings, ceramic fibers, microporous inorganic membranes, monolithic ceramics and glasses and highly porous aerogel materials [106]. This technique has always been an attractive technique for fabrication of bone scaffolds. For example, recently Zhang et al. [107] produced hierarchically porous hydroxyapatite bone scaffolds by a sol-gel method and reported that in comparison with powder sintering techniques, the sol-gel method offers the use of lower sintering temperatures, chemical purity and larger surface areas. Low temperature of operation and the possibility of producing compositions, which are not possible by other techniques, are among the main advantages of the sol-gel technique. However, this technique has some drawbacks as well, for example residual organic solvents in the scaffolds might have health implications or large volume shrinkage and cracking during drying, which can cause some mechanical strength deterioration [108]. In terms of mechanical strength improvement, Chen et al. [109] proposed a modified sol-gel process to fabricate sodium oxide-containing bioactive glass ceramics. They reported structures showing improved mechanical strength, without losing biodegradability. 


\subsubsection{Gas Foaming}

Gas foaming is a method for creating synthetic porous structures through generation of gas bubbles within a polymer with no need to use organic or cytotoxic solvents. In this technique, inert gas-foaming agents such as carbon dioxide or nitrogen are used to pressurize molded polymers until they become saturated and full of gas bubbles. The resultant sponge-like structure will have an average pore size in the range of $30-700 \mu \mathrm{m}$ and a porosity up to $85 \%$ [106]. As an example, for bone scaffold applications, Giannitelli et al. successfully fabricated polyurethane-based scaffolds by gas foaming consisting of a dense shell and a porous core thereby allowing tissue ingrowth and bone regeneration [110]. It should be noted that even though the resultant scaffold is very porous most of the pores are closed as the result of rapid depletion of the gas between pores [111]. Beside using high temperatures, the process is limited in its ability to produce consistently repeatable results. Pore formation does not occur in a predictable manner each time the technique is used. Aimed to create better interconnected pores in the gas-foaming method, this technique has been associated with a leaching method. For example, Harris and et al. combined gas foaming with leaching when they successfully produced PGLA scaffolds, displaying better interconnectivity between pores and 97\% porosity overall [112].

\subsubsection{Freeze Drying}

Freeze drying-also known as lyophilizationor cryodesiccation- is a low temperature dehydration process. In this technique, synthetic or natural polymer is dissolved in a solvent and then the solution is cooled below its freezing point while the pressure is intentionally decreased. These imposed conditions lead to solidification of the solution and sublimation (transformation of solid state into gas). The resultant would be a porous dry scaffold. One advantage of this method is the possibility to avoid high temperatures that could adversely affect the activity of incorporated biological factors. Lengthy procedure, high energy consumption and toxic solvents as well as irregular, small size pores (typically less than $35 \mu \mathrm{m}$ ) are among the disadvantages of freeze-drying [113-115]. To increase the pore size, some modifications have been applied to this technique such as adding annealing process or changing the range of freezing. In this regard collagen-glycosaminoglycan scaffolds fabricated with these modifications and a significant improvement in pore size $(85-325 \mu \mathrm{m})$ has been reported [116].

\subsubsection{Electrospinning}

Electrospinning uses an electrostatic field to charge the droplets of polymer solution ejected from a metallic needle. As the solution is ejected from the needle, it gets exposed to a very high voltage supplied between the needle and grounded collector, drawing the jet stream toward the collector and solidifying it to form a nonwoven fibrous membrane [114, 115]. Electrospinning is a versatile technique in terms of processing a wide range of materials. Furthermore, nanofibers can be functionalized with added bioactive species [117] [118], and the morphology and porosity of fibers can be manipulated by tuning process parameters. Yang et al. [119] used a combination of PCL and chitosan to create bioactive nanofibers by electrospinning. Pure electrospun chitosan has poor mechanical properties, and pure PCL electrospun shows limited cell adhesion. However, a combination of polymers resulted in a significant 
increase of both characteristics and a better ability to promote bone tissue formation. A main disadvantage of electrospinning is the use of organic solvents.

\subsubsection{Powder Forming Process}

This process involves creating a suspension of ceramic particles in a suitable liquid (such as water or ethanol) to create a slurry. The next step is fabrication of a so-called green body. The methods for forming green bodies are categorized as dry or wet processes. Among these processes, the replication method, known as a polymer-sponge, offers the potential of forming a uniform distribution of ceramic powders within a template, leading to both the desired pore size and interconnected pores. Chen et al. [120] used a powder forming process to fabricate a silicate bio glass scaffold with a porosity of about $90 \%$ and a pore size ranging from 510 to $720 \mu \mathrm{m}$. Even though the resultant scaffolds showed acceptable mechanical strength as well as biodegradability and bioactivity, protein adhesion to the surface was poor, which was improved later by applying a 3-aminopropyl-triethoxysilane coating [121].

\subsubsection{Solvent-Casting and Particle Leaching (SCPL)}

Solvent-casting and particle leaching is a popular method to produce polymer-based scaffolds for bone tissue. In this technique, first the polymer is dissolved in a solvent, later an insoluble salt is added to the solution, then the solvent is evaporated out of the system. The remaining scaffold is a saltpolymer composite; the salt will eventually be immersed in the water and salt particles will be washed out [122]. SCPL is easy to handle and does not require very expensive instruments. It should be noted that highly porous scaffolds and the ability to tune the pore sizes are the main advantages of this technique, providing the ability to make scaffolds like the structure of real bone. [106,115]. However, the technique is limited to simple shapes and the remaining toxic solvents in the structures are the drawbacks of SCPL [123-127].

\subsubsection{Thermally Induced Phase Separation (TIPS)}

Thermally induced phase separation is a method for preparing a polymeric scaffold by mixing the polymer with a solvent at high temperature and casting the solution into a film. As the solution is cooled, it separates in two phases: one polymer-rich and the other polymer-poor. The polymer-rich phase solidifies and the polymer poor one is removed, leaving a highly porous, nanoscale fibrous network. TIPS is one of the most versatile methods to produce porous polymeric scaffolds. One of the advantages of this technique is the possibility to obtain a well-interconnected polymer network with an easy-to-tune, fast and adaptable process. As a function of the separation conditions, it is possible to obtain a wide range of different morphologies with various characteristics, such as: open or closed pores, fibrous structure, membrane/like architecture, etc. [128-131]. Some polymers that have been used with this technique are polylactic acid [132], polyurethane [133], polycaprolactone [134], etc. Despite being a simple technique, phase separation remains a laboratory-scale procedure that is limited to a few polymers [135]. Extra heat treatment such as annealing is needed to compensate the effects of rapid evaporation and induced stresses [136]. 


\subsubsection{Microsphere Sintering}

In this method, a microsphere composite of ceramic and polymer that is produced by the emulsion/solvent evaporation technique, is sintered and 3D porous scaffolds are obtained. Microsphere-based scaffold fabrication techniques have attracted attention because these scaffolds may provide excellent initial mechanical properties and allow for controlled release of bioactive molecules to promote tissue regeneration [137]. In terms of strength, scaffolds made of sintered microspheres show excellent mechanical properties comparable to cancellous bone. Time, duration, and temperature are key process factors in this technique and optimization of process parameters in order to reach the desired porosity and strength seems necessary. For example, higher temperature and a longer time give superior fusion of microspheres, a smaller pore size with lower porosity, and better mechanical properties [138-141]. Since this process deals with high temperatures, it is not possible to implement the bioactive species into the microstructure of scaffold as processing.

Table 3 Advantages and disadvantages of conventional methods for fabrication of bone scaffolds.

\begin{tabular}{|c|c|c|c|}
\hline Method & Main Advantages & Main Disadvantages & Reference \\
\hline Sol-Gel & $\begin{array}{l}\text { Low temperature } \\
\text { process, chemical purity, } \\
\text { very porous structure }\end{array}$ & $\begin{array}{l}\text { Residual organic solvents, } \\
\text { large volume shrinkage and } \\
\text { cracking during drying }\end{array}$ & [109] \\
\hline Gas Foaming & $\begin{array}{l}\text { No organic or toxic } \\
\text { solvent }\end{array}$ & $\begin{array}{l}\text { Inconsistent process, high } \\
\text { temperatures, closed pores }\end{array}$ & {$[111,112]$} \\
\hline Freeze Drying & $\begin{array}{l}\text { Highly porous scaffold, } \\
\text { Low temperature } \\
\text { process }\end{array}$ & $\begin{array}{l}\text { Lengthy procedure, toxic } \\
\text { solvents, irregular and small } \\
\text { size pores }\end{array}$ & [113-115] \\
\hline Electrospinning & $\begin{array}{l}\text { Versatile technique, } \\
\text { control on morphology } \\
\text { and porosity of fibers }\end{array}$ & Organic solvents & {$[117,118]$} \\
\hline Powder Forming & $\begin{array}{l}\text { Desired pore size and } \\
\text { interconnected pores }\end{array}$ & $\begin{array}{l}\text { Poor mechanical strength } \\
\text { poor cell adhesion }\end{array}$ & {$[120,121]$} \\
\hline
\end{tabular}




\author{
Solvent-Casting \\ and Particle \\ leaching (SCPL)

$$
\begin{aligned}
& \text { High scaffold porosity } \\
& \text { and the feasibility to } \\
& \text { tune pore size }
\end{aligned}
$$

Thermally

Induced Phase Separation (TIPS)

Microsphere

Sintering
Versatile technique, fast and adaptable process.

$$
\begin{gathered}
\text { Limitation to simple shape } \\
\text { scaffolds, harmful residual } \\
\text { solvent }
\end{gathered}
$$

Difficult to precisely control the scaffold morphology, extra post heat treatment might needed

[138-141]

\subsection{Additive Manufacturing Techniques}

Since 1986 when the first commercial AM technique was introduced by 3D System ${ }^{\circledR}$, AM methods have been widely specialized and expanded over the years [142]. Recently AM has touched many industries from agriculture to automotive and military but one of the most promising sectors that AM is revolutionizing is the biomedical industry. Due to the possibility of integration with medical imaging systems to obtain customized models and, in some cases, incorporation of biomolecules or drugs, AM provides solutions to health problems, unreachable until a few years ago. In bone tissue engineering, AM techniques are now well accepted as precise and reliable manufacturing techniques and are rapidly gaining popularity. In the following sections, the most common AM techniques, which can be used for fabrications of bone scaffolds, will be discussed.

\subsubsection{Stereolithography Apparatus (SLA)}

Stereolithography Apparatus or simply stereolithography, also known as Photopolymerization, is the first AM technique. Proposed by Hull in 1980's [143], it's still one of the most widely used AM techniques. SLA uses an ultraviolet light or laser focused on a free surface of a photosensitive liquid resin to induce polymerization and transform that region into a polymerized solid [144]. The process of SLA involves with following stages [145, 146]:

- $\quad$ Light emits to the surface of a photopolymer solution based on the designed pattern.

- UV light transforms the liquid resin into a solid to form the first layer of design on a portable platform.

- The platform moves down and again light emits to the expected points of design. Following the same steps, the desired geometry forms layer by layer.

- As desired geometry is completed, the reaming solution will be removed.

- Post-processing steps such as polymerization improvement or surface polishing might be needed. 


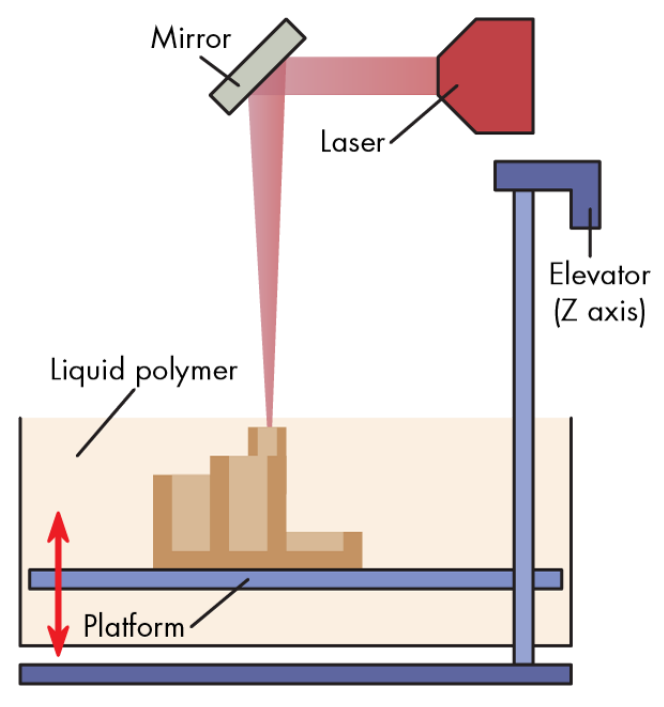

Figure 5 Schematic view of SLA method, Image courtesy of Machine Design ${ }^{\circledR}$ Co [147].

SLA can provide the highest resolution among all the AM techniques. The average achievable resolution is around $150 \mu \mathrm{m}$; however, with recent instrumental improvements, resolutions as small as 0.5 up to $10 \mu \mathrm{m}$ are even possible [148-151]. The main drawback of the SLA method is its limitation to photosensitive polymers or their composites. Historically, photosensitive polymers were not biocompatible, limiting the use of SLA for fabrication of tissue engineering scaffolds. Despite this limitation, the advantages of the SLA method were captured by using it indirectly. For instance, Levy and his colleagues in 1999 [152, 153], mixed a non-biocompatible, photosensitive acrylic polymer resin with Hydroxyapatite (HA) powder. Although the object fabricated by SLA had the desired shape, the final product had to undergo a heat treatment process in order to remove residual acrylic resin. Even though the technique was successful, the possibility of remaining toxic resins in the structure of scaffold is not acceptable. Later due to the development of biocompatible, photocurable polymers, SLA received more attention for fabrication of bone scaffolds. Matsuda et al were the first researchers implementing SLA using biocompatible polymers [153]. It should be noted, despite the progress on biocompatible, photocurable polymers, the number of such polymers remains limited [155]. Some researchers have reported disadvantages such as shrinkage of the structure during the production process, as well as in some cases instability of the printed part during the process and the need for fixtures and complications of loading bioactive agents into the structure [146]. Recent advances in stereolithography has solved aspects of these limitations. For example, a multi-material stereolithography (MMSL) machine has been developed, which enables the use of multiple materials for fabrication of an object [156]. Another improvement in SLA instruments is increasing the speed of manufacturing by implementing a digital micro-mirror device. By using this innovation instead of point to point light exposure, the machine applies arrays of many independent-rotating mirrors to the larger areas of the pattern in a way that a complete layer of resin can be cured at once, significantly decreasing the production time [157]. Other improvements on manufacturing speed were accomplished by continuously providing a layer of liquid instead of a step by step process of liquid solidification with stopping intervals [158]. Another important 
progress on SLA systems is the possibility of encapsulating cells or bio-agents, which finally made this technique applicable in tissue engineering, especially in bone scaffolds fabrication $[159,160]$.

\subsubsection{Selective Laser Sintering (SLS)}

In SLS a high-energy laser beam sequentially fuses particles directly into complex, net-shaped, 3D objects in a layer-by-layer manner, which is controlled by computer. The powders can be thermoplastic, metal, ceramic or glass $[161,162]$. In fact, in this technique, the model is analyzed and then the design is segmented into thin cross sections, typically less than $0.25 \mathrm{~mm}$. Later, these cross sections are used as building layers of the object [163]. This technique generally includes the following steps.

i. Sequential preparation of a powder bed in a way that a new layer will be placed on previous one.

ii. The light touches special points of the powder bed according the desired pattern.

iii. Remaining non-sintered powders will be removed.

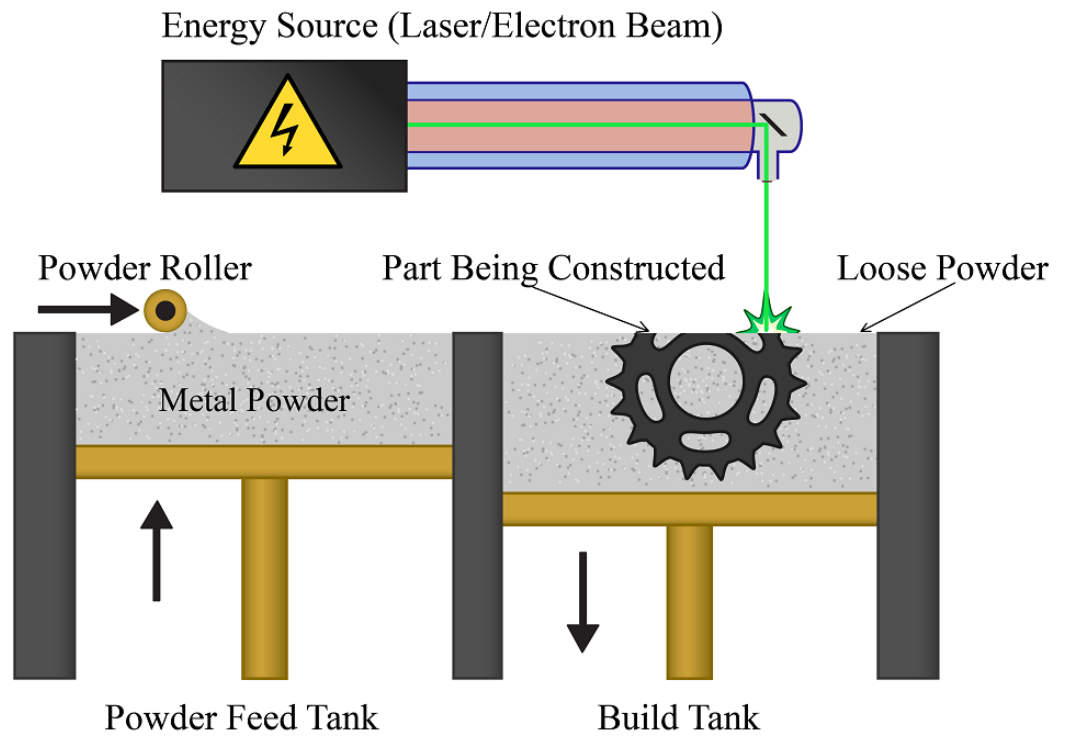

Figure 6 Schematic view of SLS method, Image courtesy of 3DEO Co [164].

SLS has received much attention in bone tissue engineering due to the easy fabrication of complicated scaffold architectures; moreover, the technique is very versatile in terms of using a wide range of materials. It has shown that both the mechanical properties and the geometry of bone scaffolds manufactured by SLS are directly dependent on infused sequential layers and process factors such as particle size, temperature of the powder bed, the intensity of the beam, scan speed and hatch distance [165-169]. Recent experimental studies have shown that the preferred particle size is 10$150 \mu \mathrm{m}$ [170]. As the speed of laser scanning decreases, particles will be exposed to the beam for longer time, which makes better sintering between particles [171-175] and therefore can determine the porosity of the structure. Another factor that affects the porosity is Hatch spacing as shown in Figure 7, which is recommended to be equal to or larger than the laser beam spot size to prevent overlap scanning (which can cause double melting or sintering) and provide adequate connectivity [162]. 


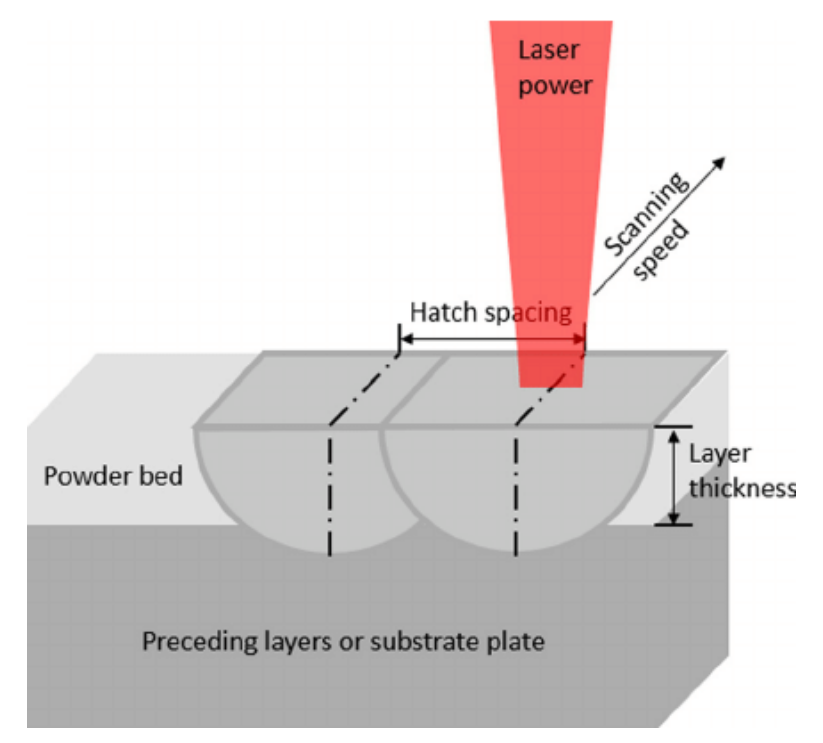

Figure 7 Hatch spacing in SLS method [176].

The main disadvantage of SLS refers to the poor mechanical strength of the fabricated scaffolds, which significantly limits the application of scaffolds, particularly in sites under load $[177,178]$. To solve this issue, in 2014, Feng et al. [179] added one more sintering step to SLS and called it novel two step sintering. In this method, after the first stage of sintering, the second sintering at a lower temperature is performed to keep the grain size at the nanoscale and to simultaneously improve the density through using grain-boundary diffusion. Another disadvantage could be the residual, non-bound material in the structure of scaffold and possibility of extremely rough surfaces. In terms of materials, several materials have been used for fabrication of scaffolds so far. One of the first bone scaffold made by SLS was successfully performed by Tan and his colleagues in 2003 [180] using polyetheretherketone (PEEK) and HA as scaffold materials. Later polycaprolactone (PCL) [167] and hydroxyapatite nanomaterials $[181,182]$ were also used to fabricate scaffolds by SLS. Poly (Hydroxybutyrate-co-Hydroxyvalerate) TriCalcium Phosphate (PHBVTCP) is one of the materials which has been used to fabricate bone scaffolds using SLS in several studies and has shown good bioactivity and acceptable strength [183-186]. Some scaffolds, on the other hand, are built using natural components such as cellulose, different polysaccharides, or collagen [187].

\subsubsection{Fused Deposition Modeling (FDM)}

FDM is based on the extrusion of a feedstock polymeric filament through a heated nozzle to deposit on a platform to build parts layer by layer. Like other AM techniques this technique is also controlled directly by a computer-aided design (CAD) system. FDM can be called the most prevalent AM technique because it constitutes almost half of the AM machines in the current global market. The FDM system is schematically shown in Figure 8 and the process basically involves the following three steps:

i. Drive wheels supply the filament into the nozzle.

ii. The filament is melted inside the extruding nozzle.

iii. The melt is extruded and continuously deposited on a platform via layer by layer deposition. 


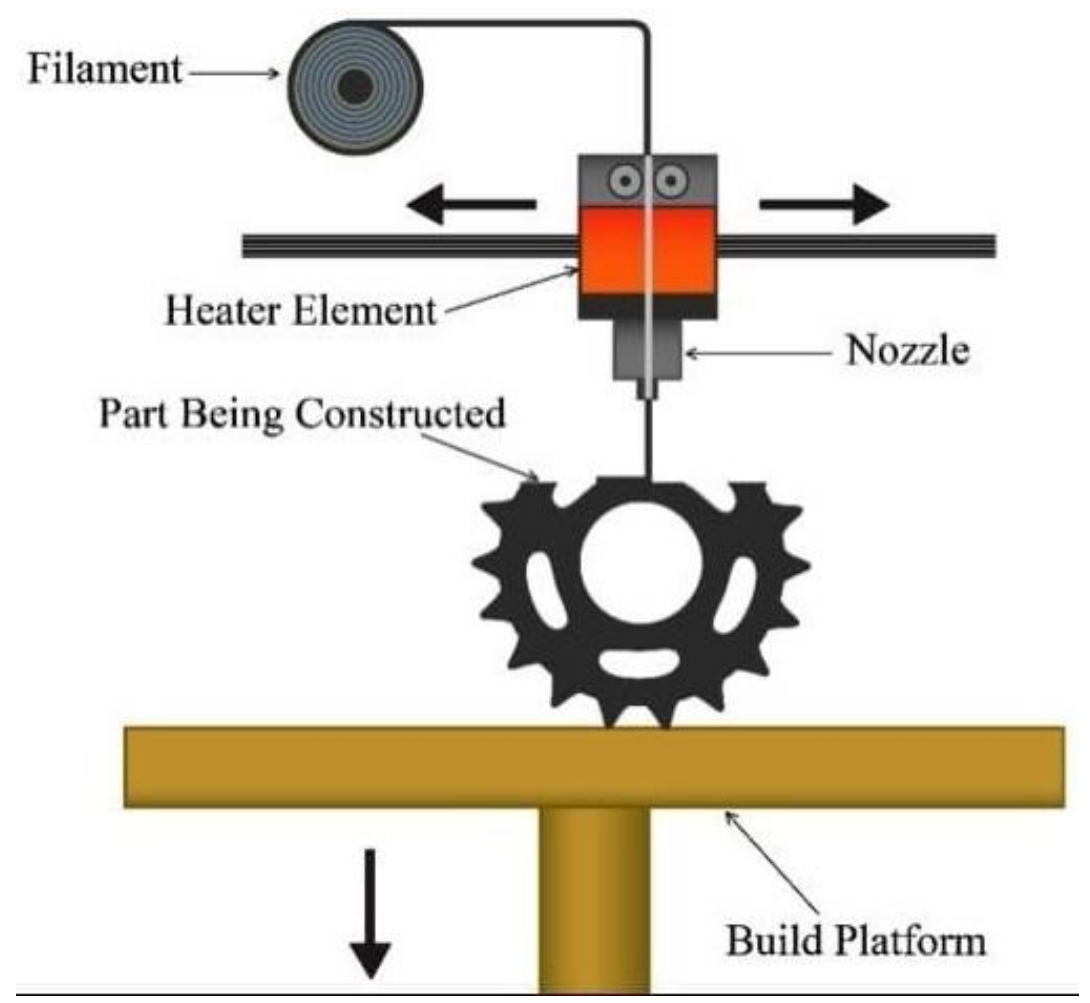

Figure 8 Schematic view of FDM method, Image courtesy of 3DEO Co [164].

It should be noted that the thickness of each depositing layer which is controlled by the movement of the platform is a very important factor for the mechanical properties of the final bone scaffold. Other important factors are the diameter of nozzle and the extrusion rate [188]. The resolution of FDM is a very delicate issue and can be easily affected by parameters such as exact synchronization between rotation of feeding wheels and the movement of the nozzle. The thermal behavior of the polymer and the amount of retained heat can also cause some unwanted deformations. This can become even more prevalent if a very porous and discontinuous scaffold is desired. One of the main drawbacks of FDM is the limited materials that can be used in this technique, which must be polymers with specific thermoplasticity, viscoelasticity and melting/solidification properties.

Recently, composite materials of polycaprolactone $(\mathrm{PCL})$ were used to fabricate scaffolds by employing FDM, and it was reported that the scaffolds supported cell growth in vitro [189-192]. Furthermore, Rohner et al. [193], reported 14.1\% generation of new bone in a pig model after three months, using PCL scaffolds prepared by FDM and coated with bone marrow. Several clinical studies have also shown that PCL scaffolds manufactured by FDM have favorable biocompatibility and a low cost of manufacturing, leading to approval by the US Food and Drug Administration for use in human bone tissue [194-197]. Currently commercialized products manufactured by FDM include Osteoplug ${ }^{\mathrm{TM}}$ and Osteomesh ${ }^{\mathrm{TM}}$ (Osteopore), which are thin interwoven meshes and three-dimensional implants respectively as it can be seen in Figure 9. 

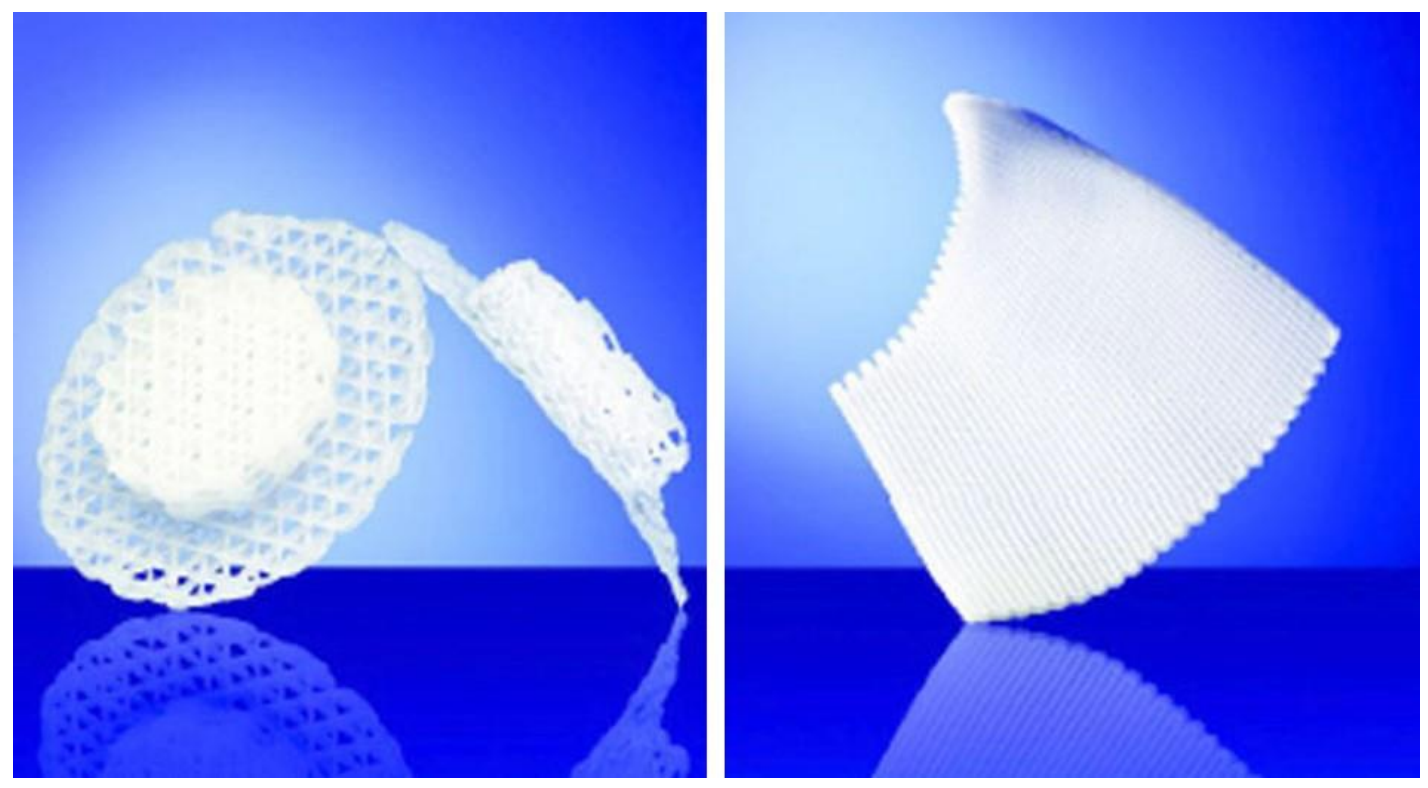

Figure 9 Osteomesh ${ }^{\mathrm{TM}}$ (left) and Osteoplug ${ }^{\mathrm{TM}}$ (right), Image courtesy of Osteopore Co [198].

As mentioned earlier, FDM is considered a limited technique in terms of materials, since only filament-shaped thermoplastic polymers can be used. Hence, in an effort to expand the repertoire of useable materials to include pellets and powders, it was suggested that melt extrusion might be used prior to FDM [146]. One of the innovations arising from FDM was using air pressure instead of rollers to push the molten polymer into the nozzle. Additionally, FDM could be combined with other techniques such as 3DP as presented by Kang et al. [199].

\subsubsection{Powder Three-Dimensional Printing (3DP)}

The powder 3D printing process begins with the powder supply being raised by a piston and a leveling roller distributing a thin layer of powder to the top of the build chamber. A multi-channel inkjet print head then deposits a liquid adhesive (wax, cyanoacrylate glue, epoxy and etc.) to targeted regions of the powder bed. These regions of powder are bonded together by adhesion and form one layer of the part. The remaining free standing powder supports the part during the build. After a layer is built, the platform is lowered and a new layer of powder added, leveled, and the printing repeated. After the part is completed, the loose supporting powder can be brushed away and the part removed. The schematic view of 3DP process is presented in Figure 10. Using 3DP, scientists can fabricate individualized bone scaffolds for the repair of complicated bone defects. For example, Grayson et al. successfully utilized the CAD/CAM 3DP system to engineer personalized, clinically sized, and anatomically shaped bone graft for the repair of a human temporomandibular joint [200]. 


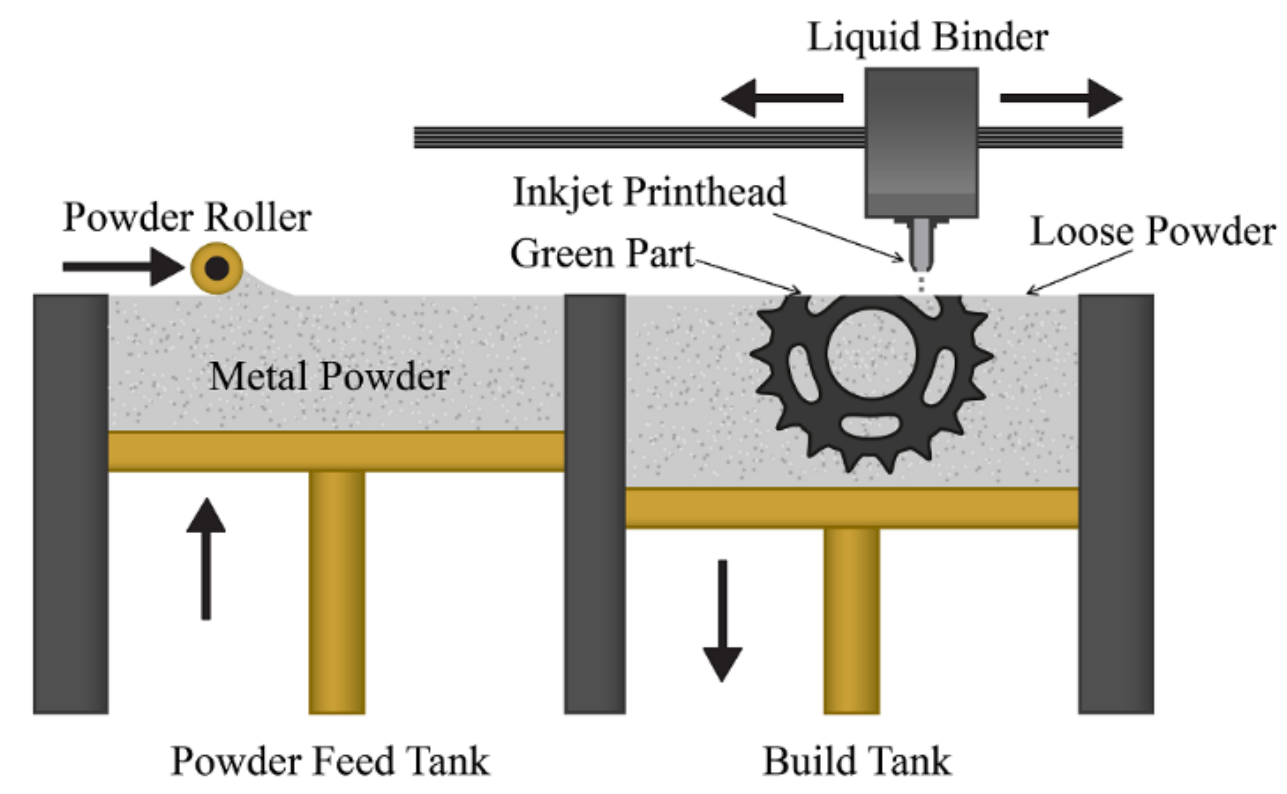

Figure 10 Schematic view of 3D powder printing method, Image courtesy of 3DEO Co [164].

The 3D powder process basically involves with following five steps:
i. Powder bed is prepared.
ii. Based on CAD file, binder is deposited on powder according desired pattern.
iii. The next powder layer is added mechanically, which binds to already deposited binder.
iv. The same above sequences are repeated until the final object is fabricated.
v. The extra unbounded powders are removed.

The remarkable advantage of this technology is in its capability to use wide range of materials including polymers, metals, ceramics and composite materials [201]. Another advantage of 3DP is the ability to use different materials in the same object. One disadvantage could be the limitation of 3DP to the powder form of materials and also in some cases the need for extra processing such as sintering. Heat treatments such as sintering not only can induce shrinkage and cracks in scaffolds but adversely affect the incorporation of bioactive molecules and drugs during the process [202-204]. The quality of bone scaffolds made by this technique are affected by several parameters, but the main ones are: flow ability and powder particle size. Low flow-ability results in poor powder compaction and decreased mechanical strength [205]. The optimum particle shape and size for printability is spherical particles with an average diameter from 20 to $35 \mu \mathrm{m}$ [205, 206]. Other factors such as binder drop volume, layer thickness, powder packing density, and powder wettability may also affect the quality of bone scaffolds $[207,208]$. Another drawback of the 3DP process is the residual, non-bound material trapped in complex geometries and the possibly of extremely rough surfaces [209].

\subsubsection{Bioprinting}

The function of bioprinters is similar to other 3D printers, with one significant difference. Instead of using printing materials such as plastic, ceramic or metal, they print layers of biomaterials, including 
proteins and living cells, in order to form tissue-like structures. Basically, to be able to print, cells need some sort of support in the form of synthetic or organic glue, dissolvable gel, collagen, etc. The cells can be precisely distributed, attach, stabilize and grow on these supportive mediums. Bioprinting technology provides precise cell distribution control [210-213].

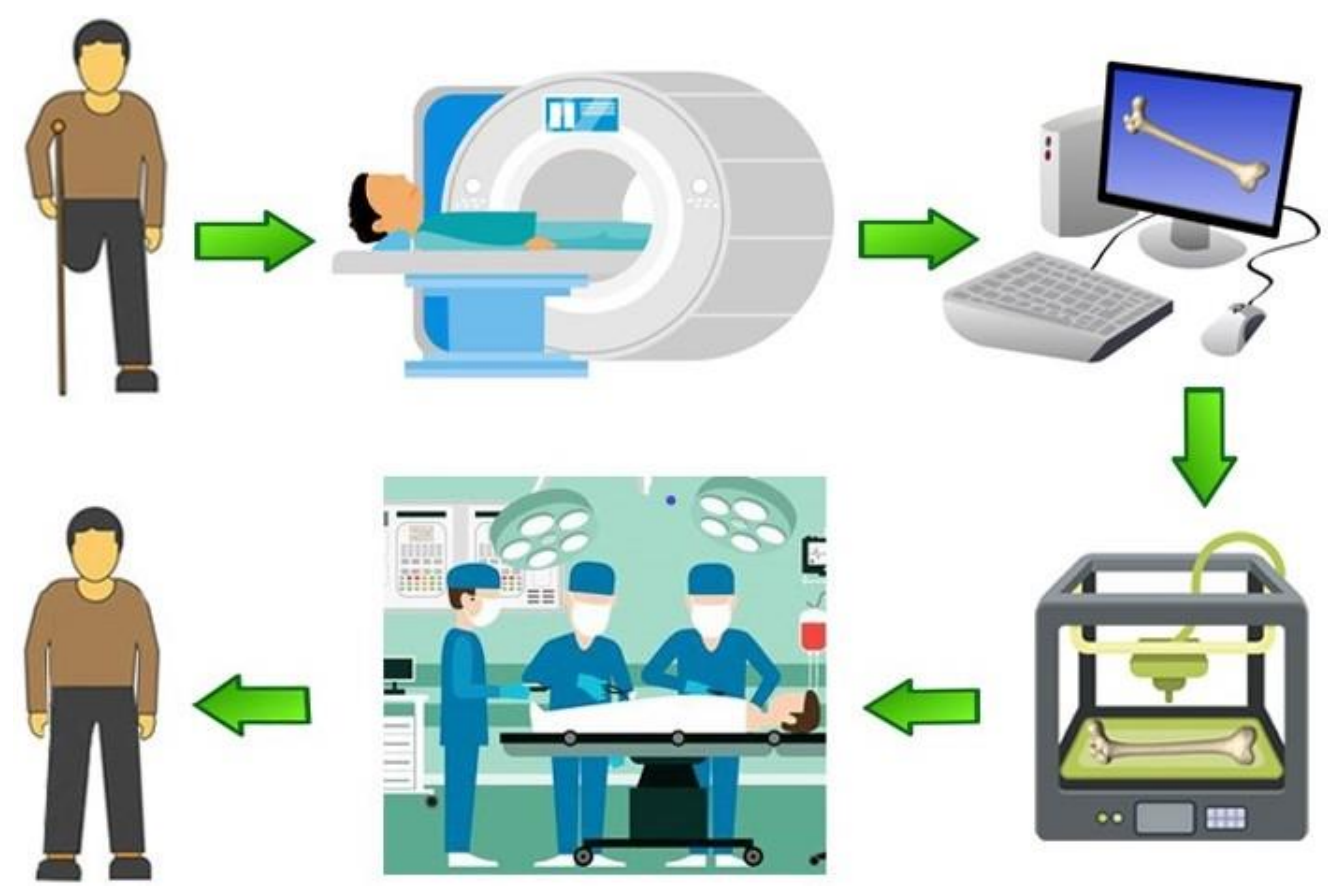

Figure 11 Schematic illustration of bone bioprinting.

It should be noted that this cutting edge aspect of additive manufacturing is very young and extensive developments needed to be accomplished before fully functional human organs can be printed and transplanted into the body as it is shown in Figure 11. To date, this technique has been mostly used to fabricate hydrogels [214]. However, hydrogels are not very attractive for bone tissue engineering due to inadequate stiffness and mechanical instability [215]. Other reported disadvantages of bioprinting are low resolution and the need to accurately match the printing cells and the liquid carrier medium. Based on instrumentation, bioprinting technology can be categorized into different methods, the most popular ones are jetting, extrusion and laser based printing [210-213]. Jetting-based bioprinting is a non-contact technique in which 2D or 3D structures are fabricated by using bio-ink droplets layered onto a substrate [216]. Extrusion-based bioprinting systems dispense continuous filaments of a material consisting of cells mixed with hydrogel through a micro-nozzle. This technique uses piston or pneumatic pressure to fabricate 2D or 3D structures. After printing 2D patterns, hydrogels are physically or chemically solidified usually by cross linking and 3D structures are fabricated by stacking patterns in a layer by layer fashion $[217,218]$. Laser-based bioprinting uses the energy of laser to transfer the cells. In fact, the embedded cells in upper layer (donor layer) are induced and extruded downward onto the collector layer based on designed pattern [210-213]. Figure 12 shows different methods of bioprinting. 


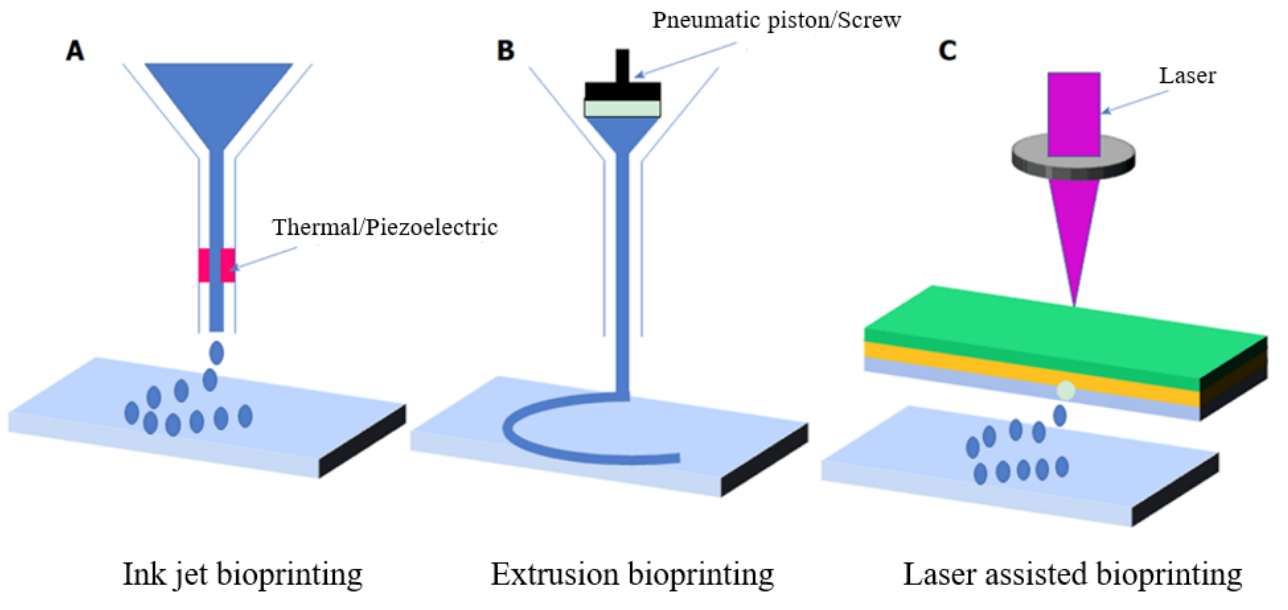

Figure 12 Different methods of bioprinting [219].

Table 4 Advantages and disadvantages of additive manufacturing techniques for fabrication of bone scaffolds.

\begin{tabular}{|c|c|c|c|}
\hline Method & Advantages & Disadvantages & References \\
\hline $\begin{array}{l}\text { Stereolithography } \\
\text { (SLA) }\end{array}$ & $\begin{array}{l}\text { High resolution, ability } \\
\text { to manufacture highly } \\
\text { complex 3D objects }\end{array}$ & $\begin{array}{l}\text { Shrinkage and } \\
\text { instability of structure } \\
\text { during process, } \\
\text { difficulty to load cells } \\
\text { into the structure }\end{array}$ & {$[156,157]$} \\
\hline $\begin{array}{l}\text { Selective laser } \\
\text { sintering (SLS) }\end{array}$ & $\begin{array}{l}\text { High geometrical } \\
\text { design freedom, high } \\
\text { flexibility, and near } \\
\text { net shape } \\
\text { production }\end{array}$ & $\begin{array}{l}\text { Low mechanical } \\
\text { properties, the residual } \\
\text { non-bounded materials } \\
\text { in geometries and } \\
\text { possibly highly rough } \\
\text { surfaces }\end{array}$ & {$[174,175]$} \\
\hline $\begin{array}{l}\text { Fused deposition } \\
\text { modeling (FDM) }\end{array}$ & $\begin{array}{l}\text { Portability and } \\
\text { simplicity, cost } \\
\text { effective }\end{array}$ & $\begin{array}{l}\text { Low resolution, long } \\
\text { working time, limited } \\
\text { shape complexity, } \\
\text { gradual deformation }\end{array}$ & {$[146,194]$} \\
\hline $\begin{array}{l}\text { Three- } \\
\text { dimensional } \\
\text { printing (3DP) }\end{array}$ & $\begin{array}{l}\text { Wide range of } \\
\text { materials, the ability } \\
\text { use of different } \\
\text { materials in the } \\
\text { same object }\end{array}$ & $\begin{array}{l}\text { Residual non-bound } \\
\text { powder in scaffold, rough } \\
\text { surfaces }\end{array}$ & [197-199] \\
\hline Bioprinting & $\begin{array}{l}\text { Desired distribution } \\
\text { of live cells in } \\
\text { scaffold }\end{array}$ & $\begin{array}{l}\text { Low resolution, still } \\
\text { more development } \\
\text { needed }\end{array}$ & {$[209,210]$} \\
\hline
\end{tabular}




\section{Conclusion and Discussion}

Current treatments for bone defects do not meet the whole patient expectations, especially by considering the growing life expectancy in recent decades. The emergence of bone tissue engineering as a significant multidisciplinary approach to treat bone issues, has opened a new horizon for a more effective, less invasive lifetime treatment of bone defects or bone loss. Bone scaffolds play a pivotal role in bone tissue engineering and there are many methods how to manufacture these biomimetic structures. Bone scaffolds can be fabricated either by conventional methods or by additive manufacturing. Conventional methods are limited in their abilities to control the required scaffold structures in terms of porosity, shape, size, distribution and interconnectivity of pores in the entire structure. Due to manufacturing conditions, it is almost impossible to include live cells within the process of conventional methods. Undesired distribution of pores might adversely affect the cell distribution and eventually affect the formation of new tissue. Also, the remaining organic solvents in the microstructure of scaffolds, can have negative impact on the viability or function of cells. However, these techniques are still being used due to minimal instrumentation and low-cost products.

Additive manufacturing is revolutionizing all sections of tissue engineering. In the case of bone tissue, AM has provided unique advantages in fabrication of bone scaffolds that are almost impossible to achieve by other techniques. AM can produce a porous scaffold with individual external shape and porous internal structure. Due to more precise control of the size, geometry and distribution of pores along with the ability to tune the mechanical and chemical properties of scaffolds, AM has enabled tissue engineers to mimic the structure of natural bone as much as its possible. Moreover, since AM techniques do not use toxic solvents, the biocompatibility of scaffolds is significantly improved. Additionally, it is possible to use two or more materials in different parts of scaffolds if needed. Despite the very good resolution of SLA and SLS techniques, their applications are very limited in fabrication of bone scaffolds. SLA is not commonly used for bone tissue applications due to the limited biocompatibility of the necessary photosensitive polymers. SLS is also is not widely used for bone tissue applications due to the high intensity laser beam, which can degrade the polymer. FDM does not have very good resolution and the applicable materials are limited; however, since the process is solventfree and very clean, it's probably the best technique to incorporate live cells, potentially explaining why PCL bone scaffolds created by FDM have received FDA approval. 3DP is applicable with a long list of biocompatible and biodegradable materials but still requires a very careful selection of binder. 3DP also requires intensive and time-consuming optimization of various parameters. Recently bioprinting has received lots of attention especially for trial printing of soft tissues using hydrogels, but in the case of bone scaffolds, more developments are needed to increase the printing resolution as well biocompatible glue or resins applicable for bone scaffolds.

Even though bone tissue engineering is rapidly growing, a long list of technical, biological and medical challenges must be addressed and solved in order to reach wide clinical applications. The proper scaffold, size, shape, interconnectivity of pores, surface roughness and correct choice of manufacturing method are all technical challenges, which need to be solved for bone tissue engineering. Furthermore, numerous in vitro and in vivo tests should be performed to ensure cell viability, survival and growth on the scaffolds. Finally, not only should the condition and expectations 
of patients as well as surgical procedures be fully considered and clarified for bone tissue engineering to become a reality, but also standardized procedures and quality control verifications need to be established to facilitate FDA approval and clinical commercialization.

Bone growth and remodeling still need more development of growth factors, and also better adaptability of fabrication process and manufacturing instruments which probably are most challenging aspects against wide commercial applications of tissue engineered bones. From biological standpoint, still important improvements needed. First of all, cell migration phenomena which leads the cells to a bone healing sites must be further understand. Moreover, how the growth factors interact with each other and with cells, preferable intracellular pathways and the way they can be activated/inactivated are the subjects that really need more research. From materials standpoint, new generation of biomaterials based on the molecular modifications are needed to stimulate specific interactions with cell integrins, direct cell proliferation, differentiation and extracellular matrix production and organization. Self-assembled materials, surface modifications such, and finally materials with appropriate porosity, degradation rates, and mechanical properties would be highly favorable. From manufacturing standpoint, new methodologies must be more improved in a way that could show more adaptation with live cells. The future techniques not only need to be extremely precise but also need to perform in absolutely controlled atmospheres with least minimum chemical contaminants. Moreover, the nature of research in bone tissue engineering is also critically important. In other words, beside technological and manufacturing progress, any development in this field, must be supported and monitored by a combination of clinical experiences, biological principles, medical necessity, and commercial practicality. By performing, comprehensive research projects from various disciplines, the gap between bone tissue engineering research and the translation into clinically available tissue engineered bones, can successfully be connected.

\section{Author Contributions}

The first author conceived the idea and wrote the paper. The second and third authors supported the manuscript by scientific and technical discussion and consultation.

\section{Competing Interests}

The authors have declared that no competing interests exist.

\section{References}

1. Baroli B. From natural bone grafts to tissue engineering therapeutics: Brainstorming on pharmaceutical formulative requirements and challenges. J Pharm Sci. 2009; 98: 1317-1375.

2. Dimitriou R, Jones E, McGonagle D, Giannoudis PV. Bone regeneration: Current concepts and future directions. BMC Med. 2011; 9: 66.

3. Yaszemski MJ, Payne RG, Hayes WC, Langer R, Mikos AG. Evolution of bone transplantation: Molecular, cellular and tissue strategies to engineer human bone. Biomaterials. 1996; 17:175-185. 
4. Soucacos PN, Johnson EO, Babis G. An update on recent advances in bone regeneration. Injury. 2008; 39: S1-S4.

5. Gazdag AR, Lane JM, Glaser D, Forster RA. Alternatives to autogenous bone graft: Efficacy and indications. J Am Acad Orthop Surg. 1995; 3: 1-8.

6. Arrington ED, Smith WJ, Chambers HG, Bucknell AL, Davino NA. Complications of iliac crest bone graft harvesting. Clin Orthop Relat Res. 1996; 329: 300-309.

7. Finkemeier CG. Bone-grafting and bone-graft substitutes. J Bone Joint Surg Am. 2002; 84: 454-464.

8. Winkler T, Sass FA, Duda GN, Schmidt-Bleek K. A review of biomaterials in bone defect healing, remaining shortcomings and future opportunities for bone tissue engineering. Bone Joint Res. 2018; 7: 232-243.

9. Zhang L, Hu J, Athanasiou KA. The role of tissue engineering in articular cartilage repair and regeneration. Crit Rev Biomed Eng. 2009; 37: 1-57.

10. Katari R, Peloso A, Orlando G. Tissue engineering and regenerative medicine: Semantic considerations for an evolving paradigm. Front Bioeng Biotechnol. 2014; 2: 57.

11. Tissue engineering and regenerative medicine. Bethesda: National Institute of Biomedical Imaging and Bioengineering (NIBIB), National Institute of Health (NIH); 2018. Available from https://www.nibib.nih.gov/science-education/science-topics/tissue-engineering-andregenerative-medicine\#pid-1156.

12. Hellman KB. Tissue engineering: Translating science to product. Topics in tissue engineering, Vol.4. Oulu: Oulu University; 2008.

13. Kim HW, Knowles JC, Kim HE. Hydroxyapatite/poly( $\varepsilon$-caprolactone) composite coatings on hydroxyapatite porous bone scaffold for drug delivery. Biomaterials. 2004; 25: 1279-1287.

14. Hauben DJ, Baruchin A, Mahler A. On the history of the free skin graft. Ann Plast Surg. 1982; 9: 242245.

15. Herman AR. The history of skin grafts. J Drugs Dermatol. 2002; 1: 298-301.

16. Rheinwatd JG, Green H. Serial cultivation of strains of human epidermal keratinocytes: Formation of keratinizing colonies from single cells. Cell. 1975; 6: 331-343.

17. Jahani B, Meesterb K, Wanga X, Brooksc A. Biodegradable magnesium-based alloys for bone repair applications: Prospects and challenges. Biomed Sci Instrum. 2020; 56: 292-304.

18. Green H, Kehinde O, Thomas J. Growth of cultured human epidermal cells into multiple epithelia suitable for grafting. Proc Natl Acad Sci USA. 1979; 76: 5665-5668.

19. O'Connor N, Mulliken J, Banks-Schlegel S, Kehinde O, Green H. Grafting of burns with cultured epithelium prepared from autologous epidermal cells. Lancet. 1981; 10: 75-78.

20. Bell E, Ehrlich HP, Buttle DJ, Nakatsuji T. Living tissue formed in vitro and accepted as skinequivalent tissue of full thickness. Science. 1981; 211: 1052-1054.

21. Atala A. Engineering tissues, organs and cells. J Tissue Eng Regen Med. 2007; 1: 83-96.

22. Berthiaume F, Maguire TJ, Yarmush ML. Tissue engineering and regenerative medicine: History, progress, and challenges. Annu Rev Chem Biomol Eng. 2011; 2: 403-430.

23. Stegemann JP, Kaszuba SN, Rowe SL. Advances in vascular tissue engineering using protein-based biomaterials. Tissue Eng. 2007; 13: 2601-2613. 
24. Hosseini-Farid M, Ramzanpour M, Ziejewski M, Karami G. A compressible hyper-viscoelastic material constitutive model for human brain tissue and the identification of its parameters. Int J Non Linear Mech. 2019; 116: 147-154.

25. Hosseini-Farid M, Ramzanpour M, Eslaminejad A, Ziejewski M, Karami G. Computational simulation of brain injury by golf ball impacts in adult and children. Biomed Sci Inst. 2018; 54: 369-376.

26. Ghosh M, Chowdhury BU, Parvej MS, Afsar AM. Modelling and stress analysis of tibia-fibula. AIP Conf Proc. 2017; 1919: 020016. doi: 10.1063/1.5018534.

27. Zaulyanov L, Kirsner RS. A review of a bi-layered living cell treatment (Apligraf ${ }^{\circledR}$ ) in the treatment of venous leg ulcers and diabetic foot ulcers. Clin Interv Aging. 2007; 2: 93-98.

28. Yano K, Tsuyuki K, Watanabe $\mathrm{N}$, Kasanuki $\mathrm{H}$, Yamato $\mathrm{M}$. The regulation of allogeneic human cells and tissue products as biomaterials. Biomaterials. 2013; 34: 3165-3173.

29. Kun M, Chan C, Ramakrishna S, Kulkarni A, Vadodaria K. Textile-based scaffolds for tissue engineering. Advanced textiles for wound care. 2nd ed. Cambridge: Woodhead Publishing; 2009. P.289-321. doi: 10.1016/B978-0-08-102192-7.00012-6.

30. Zeng W, Zhang S, Liu D, Chai M, Wang J, Zhao Y. Preclinical safety studies on autologous cultured human skin fibroblast transplantation. Cell Transplant. 2014; 23: 39-49.

31. Ikawa T, Yano K, Watanabe N, Masamune K, Yamato M. Non-clinical assessment design of autologous chondrocyte implantation products. Regen Ther. 2015; 1: 98-108.

32. Wen B, Freilich M, Kuhn L. Bone tissue engineering around dental implants. Stem cell biology and tissue engineering in dental sciences. Cambridge: Academic Press; 2015. p.749-764. doi:10.1016/B978-0-12-397157-9.00059-X.

33. Davies SD, Ochs MW. Bone morphogenetic proteins in craniomaxillofacial surgery. Oral Maxillofac Surg Clin North Am. 2010; 22: 17-31.

34. Shimono K, Oshima M, Arakawa H, Kimura A, Nawachi K, Kuboki T. The effect of growth factors for bone augmentation to enable dental implant placement: A systematic review. Jap Dent Sci Rev. 2010; 46: 43-53.

35. Brehmer B, Rohrmann D, Becker C, Rau G, Jakse G. Different types of scaffolds for reconstruction of the urinary tract by tissue engineering. Urol Int. 2007; 78: 23-29.

36. Atala A. Bioengineered tissues for urogenital repair in children. Pediatr Res. 2008; 63: 569-575.

37. Minuth WW, Strehl R, Schumacher K. Tissue engineering: Essentials for daily laboratory work. Hoboken: John Wiley \& Sons; 2003. doi: 10.1002/3527604782.

38. NIH stem cell information home page. Bethesda, MD: National Institutes of Health, U.S. Department of Health and Human Services; 2016. Available from: https://stemcells.nih.gov/info/basics.htm.

39. I. Introduction: What are stem cells, and why are they important? Bethesda, MD: National Institutes of Health, U.S. Department of Health and Human Services; 2016. Available from: https://stemcells.nih.gov/info/basics/I.htm.

40. Zhou $P, X i a ~ Y$, Cheng $X$, Wang $P, X i e ~ Y, X u S$. Enhanced bone tissue regeneration by antibacterial and osteoinductive silica-HACC-zein composite scaffolds loaded with rhBMP-2. Biomaterials. 2014; 35: 10033-10045. 
41. Jahani B, Brooks A, Azarmi F. Development of antibacterial surfaces via thermal spray coating techniques. Biomed Sci Instrum. 2018; 54: 116-122.

42. Wiedmer D, Cui C, Weber F, Petersen FC, Tiainen H. Antibacterial surface coating for bone scaffolds based on the dark catalytic effect of titanium dioxide. ACS Appl Mater Interfaces. 2018; 10: 3578435793.

43. Hasan R, Schaner K, Schroeder M, Wohlers A, Shreffler J, Schaper C, et al. Extended release combination antibiotic therapy from a bone void filling putty for treatment of osteomyelitis. Pharmaceutics. 2019; 11: 592.

44. Blackwood KA, Bock N, Dargaville TR, Ann Woodruff M. Scaffolds for growth factor delivery as applied to bone tissue engineering. Int J Polymer Sci. 2012; 2012: 174942. doi: 10.1155/2012/174942.

45. Bao CL, Teo EY, Chong MS, Liu Y, Choolani M, Chan JK. Advances in bone tissue engineering. Regenerative medicine and tissue engineering. London: IntechOpen Limited; 2013. P.599-614.

46. Van der Stok J, Van Lieshout EM, El-Massoudi Y, Van Kralingen GH, Patka P. Bone substitutes in The Netherlands - A systematic literature review. Acta Biomater. 2011; 7: 739-750.

47. Kundu ZS, Gupta V, Sangwan SS, Rana P. Curettage of benign bone tumors and tumor like lesions: A retrospective analysis. Indian J Orthop. 2013; 47: 295-301.

48. Ramzanpour M, Eslaminejad A, Hosseini-Farid M, Ziejewski M, Karami G. Comparative study of coup and countercoup brain injury in impact induced TBI. Biomed Sci Instrum. 2018; 54: 76-82.

49. Chocholata $P$, Kulda V, Babuska V. Fabrication of scaffolds for bone-tissue regeneration. Materials. 2019; 12: 568.

50. Dhandayuthapani B, Yoshida Y, Maekawa T, Kumar DS. Polymeric scaffolds in tissue engineering application: A review. Int J Polym Sci. 2011; 2011: 290602.

51. Petite $H$, Viateau V, Bensaid W, Meunier A, de Pollak C, Bourguignon $M$, et al. Tissue-engineered bone regeneration. Nat Biotechnol. 2000; 18: 959-963.

52. Green D, Howard D, Yang X, Kelly M, Oreffo RO. Natural marine sponge fiber skeleton: A biomimetic scaffold for human osteoprogenitor cell attachment, growth, and differentiation. Tissue Eng. 2003; 9: 1159-1166.

53. Midha S, Kim TB, van den Bergh W, Lee PD, Jones JR, Mitchell CA. Preconditioned 70S30C bioactive glass foams promote osteogenesis in vivo. Acta Biomater. 2013; 9: 9169-9182.

54. Woodruff MA, Lange C, Reichert J, Berner A, Chen F, Fratzl P, et al. Bone tissue engineering: From bench to bedside. Mater Today. 2012; 15: 430-435.

55. Evans $\mathrm{CH}$. Barriers to the clinical translation of orthopedic tissue engineering. Tissue Eng Part $\mathrm{B}$ Rev. 2011; 17: 437-441.

56. Balagangadharan K, Dhivya S, Selvamurugan N. Chitosan based nanofibers in bone tissue engineering. Int J Biol Macromol. 2017; 104: 1372-1382.

57. Hankenson KD, Zimmerman G, Marcucio R. Biological perspectives of delayed fracture healing. Injury. 2014; 45: S8-S15.

58. Kolk A, Handschel J, Drescher W, Rothamel D, Kloss F, Blessmann M, et al. Current trends and future perspectives of bone substitute materials - from space holders to innovative biomaterials. J Craniomaxillofac Surg. 2012; 40: 706-718. 
59. Mouriño V, Boccaccini AR. Bone tissue engineering therapeutics: Controlled drug delivery in threedimensional scaffolds. J R Soc Interface. 2010; 7: 209-227.

60. Jones AC, Arns CH, Sheppard AP, Hutmacher DW, Milthorpe BK, Knackstedt MA. Assessment of bone ingrowth into porous biomaterials using micro-ct. Biomaterials. 2007; 28: 2491-2504.

61. Bose S, Vahabzadeh S, Bandyopadhyay A. Bone tissue engineering using 3D printing. Mater Today. 2013; 16: 496-504.

62. Liu Y, Lim J, Teoh SH. Development of clinically relevant scaffolds for vascularised bone tissue engineering. Biotechnol Adv. 2013; 31: 688-705.

63. Wu S, Liu X, Yeung KW, Liu C, Yang X. Biomimetic porous scaffolds for bone tissue engineering. Mater Sci Eng R Rep. 2014; 80: 1-36.

64. Thilmany J. 3D printing scaffolds for bone. New York: The American Society of Mechanical Engineers; 2017. Available from: https://www.asme.org/topics-resources/content/3d-printingscaffolds-for-bone.

65. De Witte TM, Fratila-Apachitei LE, Zadpoor AA, Peppas NA. Bone tissue engineering via growth factor delivery: From scaffolds to complex matrices. Regen Biomater. 2018; 5: 197-211.

66. Tamaddon M, Samizadeh S, Wang L, Blunn G, Liu C. Intrinsic osteoinductivity of porous titanium scaffold for bone tissue engineering. Int J Biomater. 2017; 2017: 5093063.

67. Dabrowski B, Swieszkowski W, Godlinski D, Kurzydlowski KJ. Highly porous titanium scaffolds for orthopaedic applications. J Biomed Mater Res B Appl Biomater. 2010; 95: 53-61.

68. Witte F, Ulrich H, Palm C, Willbold E. Biodegradable magnesium scaffolds: Part II: Peri-implant bone remodeling. J Biomed Mater Res A. 2007; 81: 757-765.

69. Balla VK, Bodhak S, Bose S, Bandyopadhyay A. Porous tantalum structures for bone implants: Fabrication, mechanical and in vitro biological properties. Acta Biomater. 2010; 6: 3349-3359.

70. Tiainen $\mathrm{H}$, Lyngstadaas SP, Ellingsen JE, Haugen HJ. Ultra-porous titanium oxide scaffold with high compressive strength. J Mater Sci Mater Med. 2010; 21: 2783-2792.

71. Fu Q, Saiz E, Rahaman MN, Tomsia AP. Bioactive glass scaffolds for bone tissue engineering: State of the art and future perspectives. Mater Sci Eng C. 2011; 31: 1245-1256.

72. Seitz H, Rieder W, Irsen S, Leukers B, Tille C. Three-dimensional printing of porous ceramic scaffolds for bone tissue engineering. J Biomed Mater Res B Appl Biomater. 2005; 74: 782-788.

73. Bose $\mathrm{S}$, Tarafder $\mathrm{S}$. Calcium phosphate ceramic systems in growth factor and drug delivery for bone tissue engineering: A review. Acta Biomater. 2012; 8: 1401-1421.

74. Panseri S, Cunha C, D'Alessandro T, Sandri M, Russo A, Giavaresi G, et al. Magnetic hydroxyapatite bone substitutes to enhance tissue regeneration: Evaluation in vitro using osteoblast-like cells and in vivo in a bone defect. PLoS One. 2012; 7: e38710.

75. Jana S, Florczyk SJ, Leung M, Zhang M. High-strength pristine porous chitosan scaffolds for tissue engineering. J Mater Chem. 2012; 22: 6291-6299.

76. Ferreira AM, Gentile $P$, Chiono V, Ciardelli G. Collagen for bone tissue regeneration. Acta Biomater. 2012; 8: 3191-3200.

77. Kim HJ, Kim UJ, Kim HS, Li C, Wada M, Leisk GG, et al. Bone tissue engineering with premineralized silk scaffolds. Bone. 2008; 42: 1226-1234. 
78. Ferrand A, Eap S, Richert L, Lemoine S, Kalaskar D, Demoustier-Champagne S, et al. Osteogenetic properties of electrospun nanofibrous PCL scaffolds equipped with chitosan-based nanoreservoirs of growth factors. Macromol Biosci. 2014; 14: 45-55.

79. Kallol KM, Motalab M, Parvej MS, Konari PR, Barghouthi H, Khandaker M. Differences of curing effects between a human and veterinary bone cement. Materials. 2019; 12: 470.

80. Kim TH, Yun YP, Park YE, Lee SH, Yong W, Kundu J, et al. In vitro and in vivo evaluation of bone formation using solid freeform fabrication-based bone morphogenic protein-2 releasing PCL/PLGA scaffolds. Biomed Mater. 2014; 9: 025008.

81. Grafahrend D, Heffels KH, Beer MV, Gasteier P, Möller M, Boehm G, et al. Degradable polyester scaffolds with controlled surface chemistry combining minimal protein adsorption with specific bioactivation. Nat Mater. 2011; 10: 67-73.

82. Roseti L, Parisi V, Petretta M, Cavallo C, Desando G, Bartolotti I, et al. Scaffolds for bone tissue engineering: state of the art and new perspectives. Mater Sci Eng C. 2017; 78: 1246-1262.

83. He G, Liu P, Tan $Q$. Porous titanium materials with entangled wire structure for load-bearing biomedical applications. J Mech Behav Biomed Mater. 2012; 5: 16-31.

84. Sansone V, Pagani D, Melato $M$. The effects on bone cells of metal ions released from orthopedic implants. A review. Clin Cases in Miner Bone Metab. 2013; 10; 34-40.

85. Witte F, Ulrich H, Palm C, Willbold E. Biodegradable magnesium scaffolds: Part II: Peri-implant bone remodeling. J Biomed Mater Res A. 2007; 81: 757-765.

86. Fernandez-Yague MA, Abbah SA, McNamara L, Zeugolis DI, Pandit A, Biggs MJ. Biomimetic approaches in bone tissue engineering: Integrating biological and physicomechanical strategies. Adv Drug Deliv Rev. 2015; 84: 1-29.

87. Lu J, Yu H, Chen C. Biological properties of calcium phosphate biomaterials for bone repair: $A$ review. RSC Adv. 2018; 8: 2015-2033.

88. Amini AR, Laurencin CT, Nukavarapu SP. Bone tissue engineering: Recent advances and challenges. Crit Rev Biomed Eng. 2012; 40: 363-408.

89. Ryan GE, Pandit AS, Apatsidis DP. Porous titanium scaffolds fabricated using a rapid prototyping and powder metallurgy technique. Biomaterials. 2008; 29: 3625-3635.

90. Jahani B, Salimi Jazi M, Azarmi F, Croll A. Effect of volume fraction of reinforcement phase on mechanical behavior of ultrahigh-temperature composite consisting of iron matrix and TiB2 particulates. J Compos Mater. 2018; 52: 609-620.

91. Jun SH, Lee EJ, Jang TS, Kim HE, Jang JH, Koh YH. Bone morphogenic protein-2 (BMP-2) loaded hybrid coating on porous hydroxyapatite scaffolds for bone tissue engineering. J Mater Sci Mater Med. 2013; 24: 773-782.

92. Wang Z, Wang K, Lu X, Li M, Liu H, Xie C, et al. BMP-2 encapsulated polysaccharide nanoparticle modified biphasic calcium phosphate scaffolds for bone tissue regeneration. J Biomed Mater Res A. 2015; 103: 1520-1532.

93. Mouriño V, Boccaccini AR. Bone tissue engineering therapeutics: Controlled drug delivery in threedimensional scaffolds. J R Soc Interface. 2010; 7: 209-227.

94. Shrivats AR, McDermott MC, Hollinger JO. Bone tissue engineering: State of the union. Drug Discov Today. 2014; 19: 781-786. 
95. Kumar A, Rao KM, Han SS. Synthesis of mechanically stiff and bioactive hybrid hydrogels for bone tissue engineering applications. Chem Eng J. 2017; 317: 119-131.

96. Chang PC, Liu BY, Liu CM, Chou HH, Ho MH, Liu HC, et al. Bone tissue engineering with novel rhBMP2-PLLA composite scaffolds. J Biomed Mater Res A. 2007; 81: 771-780.

97. Shojaeiarani J, Bajwa D, Shirzadifar A. A review on cellulose nanocrystals as promising biocompounds for the synthesis of nanocomposite hydrogels. Carbohydr polym. 2019; 216: 247259.

98. Shojaeiarani J, Bajwa DS, Rehovsky C, Bajwa SG, Vahidi G. Deterioration in the physico-mechanical and thermal properties of biopolymers due to reprocessing. Polymers. 2019; 11: 58.

99. Park KH, Kim H, Moon S, Na K. Bone morphogenic protein-2 (BMP-2) loaded nanoparticles mixed with human mesenchymal stem cell in fibrin hydrogel for bone tissue engineering. J Biosci Bioeng. 2009; 108: 530-537.

100. Croisier F, Jérôme C. Chitosan-based biomaterials for tissue engineering. Eur Polym J. 2013; 49 : 780-792.

101.Polo-Corrales L, Latorre-Esteves M, Ramirez-Vick JE. Scaffold design for bone regeneration. J Nanosci Nanotechnol. 2014; 14: 15-56.

102. Gan Q, Zhu J, Yuan Y, Liu H, Qian J, Li Y, et al. A dual-delivery system of pH-responsive chitosanfunctionalized mesoporous silica nanoparticles bearing BMP-2 and dexamethasone for enhanced bone regeneration. J Mater Chem B. 2015; 3: 2056-2066.

103.Jayaraman P, Gandhimathi C, Venugopal JR, Becker DL, Ramakrishna S, Srinivasan DK. Controlled release of drugs in electrosprayed nanoparticles for bone tissue engineering. Adv Drug Deliv Rev. 2015; 94: 77-95.

104. Venkatesan J, Anil S, Kim SK, Shim MS. Chitosan as a vehicle for growth factor delivery: Various preparations and their applications in bone tissue regeneration. Int J Biol Macromol. 2017; 104 : 1383-1397.

105. Brinker CJ, Scherer GW. Hydrolysis and condensation II-silicates. Sol-gel science, The physics and chemistry of sol-gel processing. Boston: Academic Press; 1990. P.97-234.

106. Thavornyutikarn B, Chantarapanich N, Sitthiseripratip K, Thouas GA, Chen Q. Bone tissue engineering scaffolding: Computer-aided scaffolding techniques. Prog Biomater. 2014; 3: 61-102.

107.Zhang X, Zhang L, Li Y, Hua Y, Li Y, Li W, et al. Template-assisted, sol-gel fabrication of biocompatible, hierarchically porous hydroxyapatite scaffolds. Materials. 2019; 12: 1274.

108. Carter CB, Norton MG. Sols, gels, and organic chemistry. Ceramic materials: Science and engineering. New York, NY: Springer; 2013. doi: 10.1007/978-0-387-46271-4_22.

109. Chen QZ, Li Y, Jin LY, Quinn JM, Komesaroff PA. A new sol-gel process for producing $\mathrm{Na}(2) \mathrm{O}-$ containing bioactive glass ceramics. Acta Biomater. 2010; 6: 4143-4153.

110. Giannitelli SM, Basoli F, Mozetic P, Piva P, Bartuli FN, Luciani F, et al. Graded porous polyurethane foam: A potential scaffold for oro-maxillary bone regeneration. Mater Sci Eng C. 2015; 51: 329-335.

111. Carter P, Bhattarai N. Chapter 7. Bioscaffolds: Fabrication and performance. Engineered Biomimicry. 1st ed. Amsterdam: Elsevier Publishing; 2013. P.161-188.

112. Harris LD, Kim BS, Mooney DJ. Open pore biodegradable matrices formed with gas foaming. J Biomed Mater Res. 1998; 42: 396-402. 
113. Matassi F, Nistri L, Paez DC, Innocenti M. New biomaterials for bone regeneration. Clin Cases Miner Bone Metab.2011; 8: 21-24.

114.Zhu N, Chen X. Biofabrication of tissue scaffolds. Advances in biomaterials science and biomedical applications. Norderstedt: Books on Demand; 2013. P.315-328. doi: 10.5772/54125.

115. Bajaj P, Schweller RM, Khademhosseini A, West JL, Bashir R. 3D biofabrication strategies for tissue engineering and regenerative medicine. Annu Rev Biomed Eng. 2014; 16:247-276.

116. Murphy CM, Haugh MG, O'brien FJ. The effect of mean pore size on cell attachment, proliferation and migration in collagen-glycosaminoglycan scaffolds for bone tissue engineering. Biomaterials. 2010; 31: 461-466.

117. Ahmadi M, Wu XF. Tunable wrinkle modes of core-shell polymer fibers in electrospinning. J Phys Commun. 2019; 3: 045001.

118. Li L, Zhou G, Wang Y, Yang G, Ding S, Zhou S. Controlled dual delivery of BMP-2 and dexamethasone by nanoparticle-embedded electrospun nanofibers for the efficient repair of critical-sized rat calvarial defect. Biomaterials. 2015; 37: 218-229.

119. Yang X, Chen X, Wang $\mathrm{H}$. Acceleration of osteogenic differentiation of preosteoblastic cells by chitosan containing nanofibrous scaffolds. Biomacromolecules. 2009; 10: 2772-2778.

120.Chen QZ, Thompson ID, Boccaccini AR. 45S5 Bioglass-derived glass-ceramic scaffolds for bone tissue engineering. Biomaterials. 2006; 27: 2414-2425.

121. Chen QZ, Rezwan K, Françon V, Armitage D, Nazhat SN, Jones FH, et al. Surface functionalization of Bioglass-derived porous scaffolds. Acta Biomater. 2007; 3: 551-562.

122. Sola A, Bertacchini J, D'Avella D, Anselmi L, Maraldi T, Marmiroli S, et al. Development of solventcasting particulate leaching (SCPL) polymer scaffolds as improved three-dimensional supports to mimic the bone marrow niche. Mater Sci Eng C Mater Biol Appl. 2019; 96: 153-165.

123. Mehrabanian M, Nasr-Esfahani M. HA/nylon 6,6 porous scaffolds fabricated by saltleaching/solvent casting technique: Effect of nano-sized filler content on scaffold properties. Int J Nanomedicine. 2011; 6: 1651-1659.

124. Cao H, Kuboyama N. A biodegradable porous composite scaffold of PGA/beta-TCP for bone tissue engineering. Bone. 2010; 64: 386-395.

125. Subia B, Kundu J, Kundu SC. Biomaterial scaffold fabrication techniques for potential tissue engineering applications. Tissue engineering. Norderstedt: Books on Demand; 2010. P.141-157. DOI: $10.5772 / 8581$.

126. Tarun G, Ajay B, Bhawna K, Sunil K, Ravi J. Scaffold: Tissue engineering and regenerative medicine. IRJP. 2011; 2: 37-42.

127. Aboudzadeh N, Imani M, Shokrgozar MA, Khavandi A, Javadpour J, Shafieyan Y, et al. Fabrication and characterization of poly(D,L-lactide-co-glycolide)/hydroxyapatite nanocomposite scaffolds for bone tissue regeneration. J Biomed Mater Res A. 2010; 94: 137-145.

128. He L, Zhang Y, Zeng X, Quan D, Liao S, Zeng Y, et al. Fabrication and characterization of poly(I-lactic acid) 3D nanofibrous scaffolds with controlled architecture by liquid-liquid phase separation from a ternary polymer-solvent system. Polymer. 2009; 50: 4128-4138. 
129. Kim JW, Taki K, Nagamine S, Ohshima M. Preparation of porous poly (I-lactic acid) honeycomb monolith structure by phase separation and unidirectional freezing. Langmuir. 2009; 25: 53045312.

130. Phaechamud T, Chitrattha S. Pore formation mechanism of porous poly (dl-lactic acid) matrix membrane. Mater Sci Eng C. 2009; 61:744-752.

131. Yang F, Murugan R, Ramakrishna S, Wang X, Ma YX, Wang S. Fabrication of nano-structured porous PLLA scaffold intended for nerve tissue engineering. Biomaterials. 2004; 25: 1891-1900.

132. Ruggiero F, Netti PA, Torino E. Experimental investigation and thermodynamic assessment of phase equilibria in the PLLA/ Dioxane/water ternary system for application in the biomedical field. Langmuir. 2015; 31: 13003-13010.

133.Jing X, Mi HY, Salick MR, Cordie T, Crone WC, Peng XF, et al. Morphology, mechanical and shape memory effects of poly (lactic acid)/thermoplastic polyurethane blend scaffolds prepared by thermally induced phase seperation. J Cell Plast. 2014; 50: 361-379.

134. Salerno A, Domingo C. Pore structure properties of scaffolds constituted by aggregated micro particles of PCL and PCL-HA processed by phase separation. J Porous Mater. 2015; 22: 425-435.

135. Ghalia MA, Dahman Y. Advanced nanobiomaterials in tissue engineering: Synthesis, properties, and applications. Nanobiomaterials in soft tissue engineering, applications of nanobiomaterials volume 5. New York: William Andrew; 2016. P.141-172.

136. Rodríguez-Hernández J. Phase structures in thin films of nanostructured polymer blends. Design and applications of nanostructured polymer blends and nanocomposite systems, a volume in micro and nano technologies. New York: William Andrew; 2016. P.313-364.

137.Jiang T, Abdel-Fattah WI, Laurencin CT. In vitro evaluation of chitosan/poly(lactic acid-glycolic acid) sintered microsphere scaffolds for bone tissue engineering. Biomaterials. 2006; 27: 4894-4903.

138. Rezwan K, Chen QZ, Blaker JJ, Boccaccini AR. Biodegradable and bioactive porous polymer/inorganic composite scaffolds for bone tissue engineering. Biomaterials. 2006; 27: 34133431.

139.Jahani B, Salimijazi M, Azarmi F. Optimization of powder metallurgy ( $P / M)$ route for fabrication of metal matrix composites reinforced by ultra high temperature ceramics. Mater Sci Technol. 2016.

140.Shi X, Su K, Varshney RR, Wang Y, Wang DA. Sintered microsphere scaffolds for controlled release and tissue engineering. Pharm Res. 2011; 28: 1224-1228.

141.Darabi A, Azarmi F. Investigation on relationship between microstructural characteristics and mechanical properties of wire-arc-sprayed Zn-Al coating. J Therm Spray Technol. 2019; 29: 297307.

142. Hull CW. Apparatus for production of three-dimensional objects by stereolithography. US Patent. 4,575,330, 1986.

143. Kietzmann J, Pitt L, Berthon P. Disruptions, decisions, and destinations: Enter the age of 3-D printing and additive manufacturing. Bus Horiz. 2015; 58: 209-215.

144. Melchels FP, Feijen J, Grijpma DW. A review on stereolithography and its applications in biomedical engineering. Biomaterials. 2010; 31:6121-6130.

145. Lan PT, Chou SY, Chen LL, Gemmill D. Determining fabrication orientations for rapid prototyping with stereolithography apparatus. Comput Aided Des. 1997; 29: 53-62. 
146. Mota C, Puppi D, Chiellini F, Chiellini E. Additive manufacturing techniques for the production of tissue engineering constructs. J Tissue Eng Regen Med. 2015; 9: 174-190.

147. Kerns J. What's the difference between stereolithography and selective laser sintering? Machine Design; 2019. Available from: www.machinedesign.com/3d-printing-cad/article/21831851/whatsthe-difference-between-stereolithography-and-selective-laser-sintering.

148.Lan PX, Lee JW, Seol YJ, Cho DW. Development of 3d ppf/def scaffolds using microstereolithography and surface modification. J Mater Sci Mater Med. 2009; 20: 271-279.

149. Choi JW, Wicker R, Lee SH, Choi KH, Ha CS, Chung I. Fabrication of 3d biocompatible/biodegradable micro-scaffolds using dynamic mask projection microstereolithography. J Mater Process Technol. 2009; 209: 5494-5503.

150. Lee JW, Ahn G, Kim DS, Cho DW. Development of nano-and microscale composite 3d scaffolds using ppf/def-ha and micro-stereolithography. Microelectron Eng. 2009; 86: 1465-1467.

151.Lu Y, Mapili G, Suhali G, Chen S, Roy K. A digital micro-mirror device-based system for the microfabrication of complex, spatially patterned tissue engineering scaffolds. J Biomed Mater Res A. 2006; 77: 396-405.

152. Levy RA, Chu TM, Halloran JW, Feinberg SE, Hollister S. CT-generated porous hydroxyapatite orbital floor prosthesis as a prototype bioimplant. AJNR Am J Neuroophthalmol. 1999; 18: 1522-1525.

153. Chu TM, Halloran JW, Hollister SJ, Feinberg SE. Hydroxyapatite implants with designed internal architecture. J Mater Sci Mater Med. 2001; 12:471-478.

154. Matsuda T, Mizutani M, Arnold SC. Molecular design of photocurable liquid biodegradable copolymers. 1. Synthesis and photocuring characteristics. Macromolecules. 2000; 33: 795-800.

155. Hutmacher DW, Sittinger M, Risbud MV. Scaffold-based tissue engineering: Rationale for computer-aided design and solid free-form fabrication systems. Trends Biotechnol. 2004; 22: 354362.

156. Choi JW, Kim HC, Wicker R. Multi-material stereolithography. J Mater Process Technol. 2011; 211: 318-328.

157. Dudley D, Duncan WM, Slaughter J. Emerging digital micromirror device (DMD) applications. Proceeding Volume 4985, MOEMS Display and Imaging Systems; 2003. doi: 10.1117/12.480761.

158. Tumbleston JR, Shirvanyants D, Ermoshkin N, Janusziewicz R, Johnson AR, Kelly D, et al. Continuous liquid interface production of 3d objects. Science. 2015; 347: 1349-1352.

159. Dhariwala B, Hunt E, Boland T. Rapid prototyping of tissue-engineering constructs, using photopolymerizable hydrogels and stereolithography. Tissue Eng. 2004; 10: 1316-1322.

160. Arcaute K, Mann BK, Wicker RB. Stereolithography of three-dimensional bioactive poly (ethylene glycol) constructs with encapsulated cells. Ann Biomed Eng. 2006; 34: 1429-1441.

161. Rengier F, Mehndiratta A, Von Tengg-Kobligk H, Zechmann CM, Unterhinninghofen R, Kauczor HU, et al. 3D printing based on imaging data: Review of medical applications. Int J Comput Assist Radiol Surg. 2010; 5: 335-341.

162. Shirazi SF, Gharehkhani S, Mehrali M, Yarmand H, Metselaar HS, Kadri NA, et al. A review on powder-based additive manufacturing for tissue engineering: Selective laser sintering and inkjet 3D printing. Sci Technol Adv Mater. 2015; 16: 033502. doi: 10.1088/1468-6996/16/3/033502. 
163. Koo JH, Ortiz R, Ong B, Wu H. Polymer nanocomposites for laser additive manufacturing. Laser additive manufacturing: Materials, design, technologies, and application. Oxford: Woodhead Publishing; 2017. P.205-235. doi: 10.1016/B978-0-08-100433-3.00008-7.

164. Sand M. Metal 3D printing: Laser sintering vs. Bulk sintering in a furnace - pros and cons. Available from: www.3dprint.com/193946.

165. Kolan KC, Leu MC, Hilmas GE, Velez M. Effect of material, process parameters, and simulated body fluids on mechanical properties of 13-93 bioactive glass porous constructs made by selective laser sintering. J Mech Behav Biomed Mater. 2012; 13: 14-24.

166. Salmoria GV, Klauss P, Paggi RA, Kanis LA, Lago A. Structure and mechanical properties of cellulose based scaffolds fabricated by selective laser sintering. Polym Test. 2009; 28: 648-652.

167. Williams JM, Adewunmi A, Schek RM, Flanagan CL, Krebsbach PH, Feinberg SE, et al. Bone tissue engineering using polycaprolactone scaffolds fabricated via selective laser sintering. Biomaterials. 2005; 26: 4817-4827.

168. Ciardelli G, Chiono V, Vozzi G, Pracella M, Ahluwalia A, Barbani N, et al. Blends of poly- $(\varepsilon-$ caprolactone) and polysaccharides in tissue engineering applications. Biomacromolecules. 2005; 6: 1961-1976.

169. Eosoly S, Brabazon D, Lohfeld S, Looney L. Selective laser sintering of hydroxyapatite/poly- $\varepsilon$ caprolactone scaffolds. Acta Biomater. 2010; 6: 2511-2517.

170. Duan B, Wang M, Zhou WY, Cheung WL, Li ZY, Lu WW. Three-dimensional nanocomposite scaffolds fabricated via selective laser sintering for bone tissue engineering. Acta Biomater. 2010; 6: 44954505.

171.Savalani MM, Hao L, Dickens PM, Zhang Y, Tanner KE, Harris RA. The effects and interactions of fabrication parameters on the properties of selective laser sintered hydroxyapatite polyamide composite biomaterials. Rapid Prototyp J. 2012; 18: 16-27.

172. Jain PK, Pandey PM, Rao PV. Effect of delay time on part strength in selective laser sintering. Int J Adv Manuf Technol. 2009; 43: 117.

173. Delavarpour N, Eshkabilov S, Bon T, Nowatzki J, Bajwa S. The performance analysis of tactile and ultrasonic sensors for planting, fertilizing, and cultivating cover crops. Proceeding of 2019 ASABE Annual International Meeting. 2019. St. Joseph: American Society of Agricultural and Biological Engineers. doi: 10.13031/aim.201901247.

174. Delavarpour N, Eshkabilov S, Bon T, Nowatzki J, Bajwa S. Performance comparison of two guidance systems for agricultural equipment navigation. Proceeding of Design, Simulation, Manufacturing: The Innovation Exchange. 2019 June 11-14; Sumy, Ukraine. Berlin: Springer. doi: 10.1007/978-3030-22365-6_54.

175. Delavarpour N, Eshkabilov S, Bon T, Nowatzki J, Bajwa S. The tractor-cart system controller with fuzzy logic rules. Appl Sci. 2020; 10: 5223.

176. Yap CY, Chua CK, Dong ZL, Liu ZH, Zhang DQ, Loh LE, et al. Review of selective laser melting: Materials and applications. Appl Phys Rev. 2015; 2: 041101.

177. Duan B, Cheung WL, Wang M. Optimized fabrication of Ca-P/phbv nanocomposite scaffolds via selective laser sintering for bone tissue engineering. Biofabrication. 2011; 3: 015001. 
178. Kolan KC, Leu MC, Hilmas GE, Brown RF, Velez M. Fabrication of 13-93 bioactive glass scaffolds for bone tissue engineering using indirect selective laser sintering. Biofabrication. 2001; 3:025004.

179. Feng P, Niu M, Gao C, Peng S, Shuai C. A novel two-step sintering for nanohydroxyapatite scaffolds for bone tissue engineering. Sci Rep. 2014; 4: 5599.

180. Amorim FL, Lohrengel A, Neubert V, Higa CF, Czelusniak T. Selective laser sintering of Mo-CuNi composite to be used as EDM electrode. Rapid Prototyp J. 2014; 20: 59-68.

181. Shuai C, Gao C, Nie Y, Hu H, Zhou Y, Peng S. Structure and properties of nanohydroxypatite scaffolds for bone tissue engineering with aselective laser sintering system. Nanotechnology. 2011; 22: 285703.

182.Zhou WY, Wang M, Cheung WL, Ip WY. Selective laser sintering of poly (Llactide)/carbonated hydroxyapatite nanocomposite porous scaffolds for bone tissue engineering. Tissue Eng. 2010, 179-204. doi: 10.5772/8574

183. Duan B, Wang M. Customized Ca-P/PHBV nanocomposite scaffolds for bone tissue engineering: Design, fabrication, surface modification and sustained release of growth factor. J R Soc Interface. 2010; 7: S615-S629.

184. Duan B, Wang M. Encapsulation and release of biomolecules from Ca-P/PHBV nanocomposite microspheres and three-dimensional scaffolds fabricated by selective laser sintering. Polym Degrad Stab. 2010; 95: 1655-1664.

185. Duan B, Wang M. Customized nanocomposite scaffolds fabricated via selective laser sintering for bone tissue engineering. Handbook of intelligent scaffold for tissue engineering and regenerative medicine. New York: Pan Stanford Publishing; 2012. P.925-953. doi: 10.4032/9789814267861.

186. Duan B, Wang M, Li ZY, Chan WC, Lu WW. Surface modification of threedimensional Ca-P/PHBV nanocomposite scaffolds by physical entrapment of gelatin and it's in vitro biological evaluation. Front Mater Sci. 2011; 5: 57-68.

187. Liao HT, Lee MY, Tsai WW, Wang HC, Lu WC. Osteogenesis of adiposederived stem cells on polycaprolactone- $\beta$-tricalcium phosphate scaffold fabricated via selective laser sintering and surface coating with collagen type I. J Tissue Eng Regen Med. 2016; 10: E337-E353.

188. Houben A, Van Hoorick J, Van Erps J, Thienpont H, Van Vlierberghe S, Dubruel P. Indirect rapid prototyping: Opening up unprecedented opportunities in scaffold design and applications. Ann Biomed Eng. 2017; 45: 58-83.

189. Probst FA, Hutmacher DW, Müller DF, Machens HG, Schantz JT. Calvarial reconstruction by customized bioactive implant. Handchir Mikrochir Plast Chir. 2010; 42: 369-373.

190.Jiang CP, Chen YY. Biofabrication of hybrid bone scaffolds using a dual-nozzle bioplotter and invitro study of osteoblast cell. Int J Precis Eng Manuf. 2014; 15:1947-1953.

191. Pati F, Song TH, Rijal G, Jang J, Kim SW, Cho DW. Ornamenting 3d printed scaffolds with cell-laid extracellular matrix for bone tissue regeneration. Biomaterials. 2015; 37: 230-241.

192. Hutmacher DW, Schantz T, Zein I, Ng KW, Teoh SH, Tan KC. Mechanical properties and cell cultural response of polycaprolactone scaffolds designed and fabricated via fused deposition modeling. J Biomed Mater Res. 2001; 55: 203-216. 
193. Rohner D, Hutmacher DW, Cheng TK, Oberholzer M, Hammer B. In vivo efficacy of bone-marrowcoated polycaprolactone scaffolds for the reconstruction of orbital defects in the pig. J Biomed Mater Res B Appl Biomater. 2003; 66: 574-580.

194. Reichert JC, Saifzadeh S, Wullschleger ME, Epari DR, Schütz MA, Duda GN, et al. The challenge of establishing preclinical models for segmental bone defect research. Biomaterials. 2009; 30: 21492163.

195. Schantz JT, Lim TC, Ning C, Teoh SH, Tan KC, Wang SC, et al. Cranioplasty after trephination using a novel biodegradable burr hole cover: Technical case report. Oper Neurosurg. 2006; 58: ONS-E176.

196. Ramzanpour M, Hosseini-Farid M, McLean J, Ziejewski M, Karami G. Visco-hyperelastic characterization of human brain white matter micro-level constituents in different strain rates. Med Biol Eng Comput. 2020; 58:2107-2118.

197. Ramzanpour M, Hosseini-Farid M, Ziejewski M, Karami G. A constrained particle swarm optimization algorithm for hyperelastic and visco-hyperelastic characterization of soft biological tissues. Int J Comput Methods Eng Sci Mech. 2020; 21: 169-184.

198. Tissue engineering products, Retrieved from Osteopore Company. Available from: www.osteopore.com/products.

199. Kang HW, Lee SJ, Ko IK, Kengla C, Yoo JJ, Atala A. A 3D bioprinting system to produce human-scale tissue constructs with structural integrity. Nat Biotechnol. 2016; 34: 312-319.

200.Grayson WL, Fröhlich M, Yeager K, Bhumiratana S, Chan ME, Cannizzaro C, et al. Engineering anatomically shaped human bone grafts. Proc Natl Acad Sci. 2010; 107: 3299-3304.

201. Jariwala SH, Lewis GS, Bushman ZJ, Adair JH, Donahue HJ. 3D printing of personalized artificial bone scaffolds. 3D Print Addit Manuf. 2015; 2: 56-64.

202. Shanjani Y, De Croos JA, Pilliar RM, Kandel RA, Toyserkani E. Solid freeform fabrication and characterization of porous calcium polyphosphate structures for tissue engineering purposes. J Biomed Mater Res B Appl Biomater. 2010; 93: 510-519.

203. Gbureck U, Hölzel T, Klammert U, Wuerzler K, Mueller FA, Barralet JE. Resorbable dicalcium phosphate bone substitutes prepared by 3D powder printing. Adv Funct Mater. 2007; 17: 39403945.

204.Gbureck U, Vorndran E, Müller FA, Barralet JE. Low temperature direct 3d printed bioceramics and biocomposites as drug release matrices. J Control Release. 2007; 122: 173-180.

205. Butscher A, Bohner M, Roth C, Ernstberger A, Heuberger R, Doebelin N, et al. Printability of calcium phosphate powders for three dimensional printing of tissue engineering scaffolds. Acta Biomater. 2012; 8: 373-385.

206. Seitz H, Deisinger U, Leukers B, Detsch R, Ziegler G. Different calcium phosphate granules for 3D printing of bone tissue engineering scaffolds. Adv Eng Mater. 2009; 11: B41-B46.

207. Tarafder S, Balla VK, Davies NM, Bandyopadhyay A, Bose S. Microwave-sintered 3D printed tricalcium phosphate scaffolds for bone tissue engineering. J Tissue Eng Regen Med. 2013; 7: 631641.

208. Amirkhani S, Bagheri R, Yazdi AZ. Effect of pore geometry and loading direction on deformation mechanism of rapid prototyped scaffolds. Acta Mater. 2012; 60: 2778-2789. 
209. Butscher A, Bohner M, Hofmann S, Gauckler L, Müller R. Structural and material approaches to bone tissue engineering in powder-based three-dimensional printing. Acta Biomater. 2011; 7: 907920.

210. Mandrycky C, Wang Z, Kim K, Kim DH. 3D bioprinting for engineering complex tissues. Biotechnol Adv. 2016; 34: 422-434.

211. Obregon F, Vaquette C, Ivanovski S, Hutmacher DW, Bertassoni LE. Three-dimensional bioprinting for regenerative dentistry and craniofacial tissue engineering. J Dent Res. 2015; 94: 143S-152S.

212. Ozbolat IT, Yu Y. Bioprinting toward organ fabrication: Challenges and future trends. IEEE Trans Biomed Eng. 2013; 60: 691-699.

213.Seol YJ, Kang HW, Lee SJ, Atala A, Yoo JJ. Bioprinting technology and its applications. Eur J Cardiothorac Surg. 2014; 46: 342-348.

214. Sawkins MJ, Mistry P, Brown BN, Shakesheff KM, Bonassar LJ, Yang J. Cell and protein compatible 3D bioprinting of mechanically strong constructs for bone repair. Biofabrication. 2015; 7: 035004.

215. Li CC, Kharaziha M, Min C, Maas R, Nikkhah M. Microfabrication of cell-laden hydrogels for engineering mineralized and load bearing tissues. Adv Exp Med Biol. 2015; 881: 15-31.

216. Gao G, Yonezawa T, Hubbell K, Dai G, Cui X. Inkjet-bioprinted acrylated peptides and PEG hydrogel with human mesenchymal stem cells promote robust bone and cartilage formation with minimal printhead clogging. Biotechnol J. 2015; 10: 1568-1577.

217. Roohani-Esfahani SI, Newman P, Zreiqat H. Design and fabrication of 3D printed scaffolds with a mechanical strength comparable to cortical bone to repair large bone defects. Sci Rep. 2016; 6: 19468.

218. Liu G, Ding Z, Yuan Q, Xie H, Gu Z. Multi-layered hydrogels for biomedical applications. Front Chem. 2018; 6: 439.

219. Kumar SA, Delgado M, Mendez VE, Joddar B. Applications of stem cells and bioprinting for potential treatment of diabetes. World J Stem Cells. 2019; 11: 13-32.

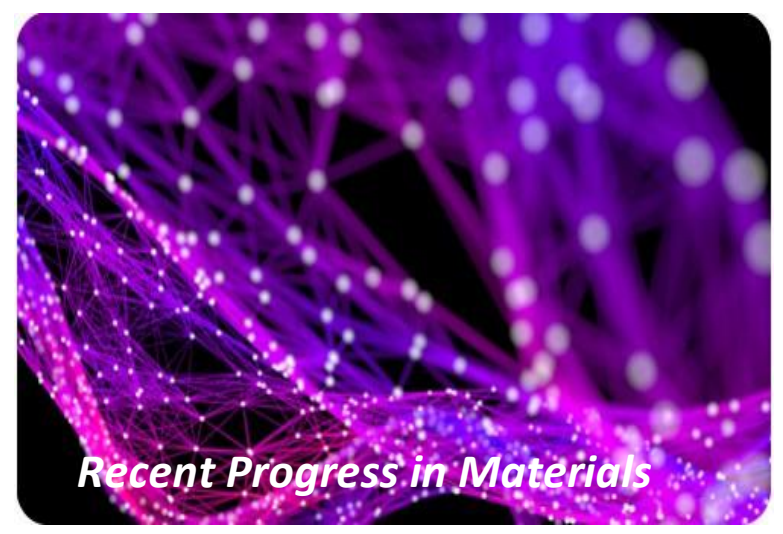

Enjoy Recent Progress in Materials by:

1. Submitting a manuscript

2. Joining in volunteer reviewer bank

3. Joining Editorial Board

4. Guest editing a special issue

For more details, please visit: http://www.lidsen.com/journals/rpm 